\title{
Wellbeing at work and the Great Recession: The effect of others' unemployment
}

\author{
Cristina Borra ${ }^{1}$ and Francisco Gómez-García ${ }^{1 *}$
}

1 University of Seville

*Corresponding author: C/ Ramón y Cajal, 1, Facultad de Ciencias Económicas y Empresariales, Departamento de Economía e Historia Económica (Universidad de Sevilla) 41018 Sevilla e-mail: fgomez@us.es

\begin{abstract}
Economists have long been interested in the possibility that individuals' wellbeing depends on their relative position. The recent recession has generated a tremendous increase in unemployment rates in Spain. In this paper we use a very rich repeated cross-section dataset on workers' job conditions, together with regional unemployment information, to investigate whether peers' unemployment affects individuals' job satisfaction. We try to distinguish both the negative effect that others' unemployment might inflict on individual on-the-job wellbeing via increased job insecurity and the positive effect, sometimes called social norm of unemployment, whereby individuals' wellbeing increases when they feel relatively better than their peers. We find that peers' unemployment shows both a negative and a positive effect in Spain. In fact, once perceived job insecurity is controlled for, a clear positive effect emerges, larger and more precisely estimated for men and private-sector workers. This result is robust to using different unemployment rate measures and, interestingly, to controlling for workforce selection. Our findings constitute a microeconometric foundation of the countercyclical pattern of productivity in Spain.
\end{abstract}

Keywords: Job satisfaction, unemployment rate, relative position, job insequrity, Spain, Great Recession 


\section{Introduction}

This paper looks at the effect of peers' unemployment on individuals' job satisfaction. We therefore focus on the following question: Does others' unemployment affect employees' job satisfaction?

Following the work of Locke (1969), Hammermesh (1977), Freeman (1978), and Borjas (1979), economists became increasingly interested in issues related to subjective evaluations of the utility derived from work as measured by stated job satisfaction since it is related to gains in productivity at an organizacional and an individual level (Mangione and Quinn 1975, Oswald 1997, Halkos and Bousinakis 2010, Bökerman and Ilmakunnas 2010, Phelps and Zoega 2013) ${ }^{1}$. The literature provides evidence for a strong relationship between wellbeing at work and specific socioeconomic characteristics, namely, gender, age, education, wages, working hours, trade unions status and establishment size (Theodossiou and Vasileiou 2007, García-Serrano 2011, Borra and Gómez 2012).

A related literature analyzes the effect of unemployment on subjective life satisfaction. Unemployment is widely considered to have a strong negative impact on individual wellbeing and losing a job is associated with a significant drop in not only income, but also social status, self-esteem, and other non-pecuniary effects (Clark and Oswald 1994, Winkelmann y Winkelmann 1998, Clark 2003, Blanchflower and Oswald 2004). Recently, evidence has gathered showing also a clear negative effect of general unemployment on subjective wellbeing among the employed in United Kingdom and Germany (Clark et al. 2010, Luechinger et al. 2010, Schwarz 2012). The most obvious channel for this effect is via the individual's perception of job insecurity: others' unemployment increases one's own risk of becoming unemployed ${ }^{2}$.

On the other hand, individual welfare may be subject to social influences. Previous literature both from economists (Duesenberry 1949; Easterlin, 1974; Solnik and Hemenway 2005; Luttmer, 2005) and psychologists (Kahneman et al. 1999; Inglehart and Klingemann 2000) highlights that individuals' welfare depends heavily on their achievement in comparison to others' outcomes. In this context, a higher level of unemployment may bring some well-being benefits by reducing expectations of success: the employed feel better off when their relative standing increases (Eggers et al. 2006).

In this paper we try to isolate both the negative insecurity effect and the positive comparison effect of unemployment rates on subjective wellbeing at work in Spain during 2006-2010. We use individual level data from the Spanish Working Conditions Survey (Encuesta de Calidad de Vida en el Trabajo

\footnotetext{
${ }^{1}$ For a survey see Pugno and Depredi (2009).

${ }^{2}$ High unemployment may also induce other general negative externalities such as a higher crime rate, expectations of higher taxes to finance increased welfare spending, and increased income inequality (Luechinger et al. 2010)
} 
(ECVT)), a yearly survey carried out by the Spanish Ministry of Labour and Social Affairs containing information on individual job satisfaction, demographic and human capital characteristics of employees, employers' features, and pecuniary and non-pecuniary job characteristics, together with regional unemployment rates computed from the Spanish Labour Force Survey (Encuesta de Población Activa, EPA) for the same years. Our identification strategy uses time and cross-section variations in the data to estimate the effect of regional unemployment rates on job satisfaction. In order to distinguish insecurity and comparison effects we compare models including and excluding perceived job insecurity measures as additional controls.

Understanding unemployment and individual wellbeing in Spain during the recent recession is especially relevant. Spain has witnessed a surge in unemployment from slightly over $8 \%$ in 2006 to more than $20 \%$ in 2010 , the highest in the European Union with the only exception of Greece. The increase has not been homogeneous, though, with some regions experiencing moderate increases (from 7 to $14 \%$ in the Basque Country) and others suffering from huge rises (from 12 to $28 \%$ in Andalusia). In addition, the recession is also having a large and damaging impact on the national debt (with risk premiums hitting historical records), on the banking sector (with some banks needing bailouts), and on the overall ability of the state to deal with these economic and political problems.

We find that, for those currently working, peers' unemployment shows both a negative insecurity effect and a positive comparison effect in Spain. In fact, once perceived job insecurity is controlled for, higher peers' unemployment rates are associated with higher job satisfaction. With the exception of Eggers et al. (2006), no previous work has obtained similar results. Using information from the British Household Panel Survey, Clark (2003) finds a clear negative effect of surrounding unemployment on life satisfaction of the employed. A similar result is reported by Powdthavee (2007) for South Africa. In Germany, with data from the German Socio-Economic Panel, Clark et al (2010) reveal a clear negative effect of others' unemployment on the general wellbeing of the employed, slightly lower for those with higher perceived insecurity, which are considered to be subject to the social norm of unemployment. Luechinger et al. (2010), with the same dataset, also show a negative effect of regional unemployment on the employed, but only significant for those who belong to the private sector. The only study obtaining a positive effect of higher unemployment rates on the wellbeing of the employed analyzes the tumultuous environment of post-Soviet Russia during the 1990s (Eggers et al. 2006).

We also investigate whether this positive effect is due to sample selection instead of individuals' relative standing. In an environment of very high unemployment, remaining workers may increasingly be selected from those who have greater motivation or better attitudes towards work, and higher job satisfaction may be just the consequence of a different workforce composition arising after the crisis. 
Using propensity score matching techniques to correct for sample selection, we rule out that our results are driven by selection effects in a significant way.

As far as we know, no previous study has examined the effect of peers' unemployment on subjective wellbeing at work in the context of the Great Recession using a survey of employees. For instance, the literature of the macroeconomics of happiness (Di Tella et al. 2001, 2003, Wolfers 2003) examines the effects of business cycle volatility on subjective well-being, but so far the recent recession has not been examined. We also add to existing literature by examining a Southern European country such as Spain. So far previous studies have focused primarily on Germany (Clark et al 2010, Luetchinger et al. 2010, Schwarz 2012), the United Kingdom (Clark 2003), South Africa (Powdthavee 2007) and Rusia (Eggers et al. 2006). Compared to these studies we control for unobserved heterogeneity by including personality and psychological attitudes in the spirit of Ferrer-i-Carbonell and Frijters 2004 and Origo and Pagani 2009 and we focus on subjective wellbeing at work controlling for a vast array of working conditions that may have hardened during the recession. Moreover, we contribute to this literature by addressing the issue of sample selection through propensity score matching methods as in Kawaguchi et al. (2012) and Borra et al. (2013). Finally, our result constitutes a microeconometric foundation of the countercyclical pattern of productivity in Spain found by Mora-Sanguinetti and Fuentes (2012), and Maroto-Sanchez and Cuadrado-Roura (2013) among others. The positive effect of unemployment on workers' wellbeing found in this paper implies that productivity increases during recessions, that is, countercyclically .

This paper is organized as follows. The next section presents the theoretical framework. Section 3 describes the dataset and the estimation procedure. Section 4 presents the results and their heterogeneity with respect to different variables. Section 5 explores sample selection issues and, finally, Section 6 concludes.

\section{Theoretical framework}

The theoretical model that supports our empirical strategy is based on the hypothesis that a job is more than the salary and number of hours of work-against reductionist vision-neoclassical approach; other job characteristics are relevant to define the job post such as, the possibility of reconciling work and family or on-the-job training. In this paper we add an additional hypothesis: does others' unemployment, as measured by regional unemployment rates, affect wellbeing at work? (Akerlof 1980 and Clark 2003). As supported by previous literatura, unemployment reduces individual welfare of those who are personally affected by it. ${ }^{3}$. However, high unemployment rates may also have nonngegligible effects on people who are not personally affected by unemployment. For instance,

\footnotetext{
${ }^{3}$ Our simple includes only those in employment. See references above.
} 
based on survey data from population samples from European Union member countries between 1975 and 1992, Di Tella et al. (2003) show than aggregate unemployment decreases average reported life satisfaction even if personal unemployment is kept constant.

The most obvious effect of general unemployment on those employed is through job insecurity: bad news for others increase my own unemployment risks, producing a clear negative effect on wellbeing. In addition, overall unemployment may also generate negative or positive externalities: a) negative , due to empathy with the unemployed workers - see Clark (2003), Clark et al. (2010), Luechinger et al. (2010), Schwarz (2012) and Hudson and Barrett ( 2013 ); and b ) positive, coming from relative achievement in comparison to others' outcomes. This positive comparison effect, profusively evidenced with respect to income (Hamermesh (1977), Clark and Oswald (1996), Solnik and Hemenway 2005; Luttmer, 2005), is most unusual with respect to unemployment in the empirical literature (Eggers et al. 2006). To distinguish between these externalities (positive and / or negative ) and changes in the economic risks that arise when having a job becomes less common, we include perceived job insecurity as a specific argument of the utility function. In light of the above, we present a model in which the individual's utility depends on perceived job insecurity and the regional unemployment:

$$
U\left(J I_{i}, U R_{r}, Z_{i}\right)
$$

where $\mathrm{U}(\cdot)$ represents utility derived from work, $\mathrm{JI}_{\mathrm{i}}$ is individual $i$ 's perceived job insecurity $i, \mathrm{U}_{\mathrm{R}}$ is region $\mathrm{r}$ unemployment rate and $\mathrm{Z}_{\mathrm{i}}$ is a vector of control variables such as gender, education, and job characteristics -including the wage rate- that may affect the individual's utility.

In the following we assume there is a relationship between current utility (U) and subjective wellbeing at work $\left(\mathrm{WAW}_{\mathrm{i}}\right)$, defined as:

$$
W A W_{i}=U\left(J I_{i}, U R_{r}, Z_{i}\right)+\varepsilon_{i}
$$

Where the error term captures individual heterogeneity, mainly due to attitudes and personality traits, and measurement error. As stated by Kahneman y Krueger (2006), subjective wellbeing at work can be inferred from individuals' satisfaction scores.

\section{Data, variables, and empirical strategy}

We use two sources of data in our analysis: (1) individual level data from the Spanish Working Conditions Survey (Encuesta de Calidad de Vida en el Trabajo (ECVT)) spanning from 2006 through 2010, and (2) data on regional unemployment rates computed from the Spanish Labour Force Survey (Encuesta de Población Activa, EPA) for the same years. 
The ECVT provides the most representative and frequent data on job satisfaction for the Spanish workforce. We use 40,000 individual records with information on demographic and human capital characteristics of employees, employers' features, and pecuniary and non-pecuniary job characteristics. We choose the 2006-2010 period in order to analyze the potential effect of unemployment during the Great Recession and because important methodological changes took place in 2006, rendering previous surveys not directly comparable to the ones we use.

The measure of overall job satisfaction is derived from the following question: "Indicate your level of satisfaction in your current job" It is measured on an ordinal 11-point Likert scale from "very badly" (0) to "excellently" (10). As a first approximation to our research question, Table 1 summarizes the dependent variable by survey year. Apparently the recession has not significantly altered the job satisfaction of those employed.

Table 1. Dependent variable

\begin{tabular}{ccccccc}
\hline Satisfaction & 2006 & 2007 & 2008 & 2009 & 2010 & $2006-2010$ \\
0 & 1.17 & 0.35 & 0.22 & 1.05 & 0.50 & 0.65 \\
1 & 0.38 & 0.28 & 0.19 & 0.50 & 0.48 & 0.37 \\
2 & 1.03 & 0.66 & 0.43 & 0.97 & 1.17 & 0.85 \\
3 & 1.54 & 1.68 & 1.43 & 1.63 & 1.44 & 1.54 \\
4 & 2.75 & 3.09 & 2.73 & 2.16 & 2.21 & 2.58 \\
5 & 10.27 & 10.95 & 9.39 & 8.38 & 8.50 & 9.48 \\
6 & 10.69 & 12.74 & 12.85 & 10.97 & 11.15 & 11.69 \\
7 & 19.30 & 22.26 & 23.20 & 22.02 & 20.81 & 21.54 \\
8 & 26.00 & 27.32 & 29.59 & 28.16 & 29.27 & 28.10 \\
9 & 12.30 & 12.19 & 11.71 & 11.35 & 12.90 & 12.09 \\
10 & 14.56 & 8.49 & 8.27 & 12.81 & 11.58 & 11.10 \\
Total & 100.00 & 100.00 & 100.00 & 100.00 & 100.00 & 100.00 \\
\hline Average & 7.33 & 7.19 & 7.27 & 7.33 & 7.37 & 7.30 \\
\hline \hline
\end{tabular}

Regional unemployment rates are provided from the EPA directly by the Spanish Statistical Office (Instituto Nacional de Estadística, 2013). Table A.1 in the Appendix shows unemployment rates by region and year as in our benchmark definition of peer's unemployment.

A major advantage of the dataset is that it contains an extremely rich set of background variables, which allows the implementation of econometric methods to a very high standard. In particular the survey offers personal and demographic characteristics, human capital features and other non-financial job characteristics -apart from job security. Table A.2 in the appendix shows definitions and descriptive statistics of all variables used in the analyses, by survey year.

Our purpose is to explore how increasing unemployment rates after the recession may have impacted individuals wellbeing at work. With that aim in mind, we estimate the following equation in our benchmark analysis 


$$
W A W_{i r t}=\alpha+\beta_{1} U R_{r}+Z_{i} \gamma+\phi_{r}+\varphi_{t}+\varepsilon_{i r t}
$$

where the dependent variable is the individual's i from region $r$ overall job satisfaction in year $t$. The variable $\mathrm{UR}_{\mathrm{r}}$ is a measure of the regional unemployment rate. We also control for a variety of individual level personal and job characteristics included in the vector $X$ known to be correlated to subjective wellbeing, such as age, gender, marital status, educational attainment, job tenure, wages, contract type, firm size, accident risk, $\ldots{ }^{4}$ We also include regional $\phi_{r}$ and year $\varphi_{t}$ fixed-effects to account for a variety of macroeconomic factors possibly correlated to individuals' welfare, such as differences in crime rates, the public provision of unemployment support, divorce rates,... Finally, standard errors are clustered at the regional level as suggested by Moulton (1990).

Absent any controls for perceived job insecurity, $\beta_{1}$ captures the combined insecurity plus comparison effects. In order to distinguish both, we also estimate a model with an additional control for subjective job insecurity

$$
W A W_{i r t}=\alpha+\beta_{2} U R_{r}+\delta J S_{i}+X_{i} \gamma+\phi_{r}+\varphi_{t}+\varepsilon_{i r t}
$$

Where JS measures satisfaction with job stability in a 0-10 scale. In this second model the coefficient of the unemployment rate $\beta_{2}$ estimates now just the comparison effect.

In our model $\beta_{1}$ in equation (3) measures the combined externality plus job insecurity effect. We expect this parameter to have a negative or nil value due to the a priori relative weight of job security on wellbeing at work. $\beta_{2}$ in equation (4) measures just the externality effect of general unemployment on job satisfaction. We expect this parameter to be larger than $\beta_{1}$ and even positive if the positive comparison effect turns larger than the negative empathic effect in Spain.

Our dependent variable is intrinsically ordered in nature. However, usual estimators like ordered probit or logit may not be flexible enough for our purposes. Van Praag and Ferrer-i-Carbonell (2006) show that the latent variable underlying an ordinal variable can be approximated by adequately rescaling the variable. Therefore, we will use this approach termed Probit OLS and transform the variable into a pseudo-continuous one as explained by Corneliben (2009) and use a traditional linear regression estimator.

\section{Results}

Table 2 presents our baseline estimates for our sample of employees. The first specification includes no additional controls. The second specification adds in a range of variables indicating demographic and human capital characteristics of the individual, while the third specification controls for job characteristics, including the individual's monthly earnings. The fourth specification includes personality and psychological attitudes, which are very likely to capture time-invariant unobserved

\footnotetext{
${ }^{4}$ We include these characteristics sequentially to assess how the estimated coefficient changes as we include some variables that could be potentially considered endogenous, as is the case with contract type or job tenure.
} 
factors in the absence of panel data (Ferrer-i-Carbonell and Frijters 2004; Origo and Pagani 2009). The fifth specification adds up region and year fixed effects while the sixth specification also includes perceived job stability.

Table 2. The effect of regional unemployment rates on subjective wellbeing at work

\begin{tabular}{lcccccc}
\hline & $(1)$ & $(2)$ & $(3)$ & $(4)$ & $(5)$ & $\begin{array}{c}(6) \\
\text { Spec. 6 }\end{array}$ \\
& Spec. 1 & Spec. 2 & Spec. 3 & Spec. 4 & Spec. 5 & \\
& & & & & & \\
Regional Unemployment Rate & $0.009^{* *}$ & $0.008^{* * *}$ & $0.009^{* * *}$ & $0.009^{* * *}$ & 0.008 & $0.010^{* *}$ \\
& $(0.003)$ & $(0.003)$ & $(0.002)$ & $(0.002)$ & $(0.005)$ & $(0.003)$ \\
Perceived Job Stability & & & & & & $0.155^{* * *}$ \\
& & & & & & $(0.003)$ \\
\hline Demographic and Human Capital Vars. & No & Yes & Yes & Yes & Yes & Yes \\
Job Characteristics & No & No & Yes & Yes & Yes & Yes \\
Personality Traits & No & No & No & Yes & Yes & Yes \\
Region fixed effects & No & No & No & No & Yes & Yes \\
Year fixed effects & No & No & No & No & Yes & Yes \\
\hline Observations & 32,290 & 32,209 & 32,290 & 32,290 & 32,290 & 32,290 \\
R-squared & 0.003 & 0.069 & 0.117 & 0.124 & 0.134 & 0.267 \\
\hline
\end{tabular}

Notes:

This table shows the regression of perceived job satisfaction on the variables of interest. The sample includes only individuals aged 16-74 who are employed in the private or public sector, and not self-employed. Regressions include a constant term together with the control variables in Table A.2 in a sequential way. Observations are weighted using the individual weights in the ECVT. Standard errors in parentheses adjusted for clustering on the regional level. * significant at $10 \% * *$ significant at $5 \%$; *** significant at $1 \%$.

Source: ECVT and EPA 2006-2010.

When comparing the estimated effect in specification (5) -equation (3)- to that in specification (6) equation (4) it becomes apparent that, after controlling for all demographic variables, job characteristics, personality traits, and regional and time variation, the general combined effects of unemployment are virtually inexistent. However, when obtaining the net effect, controlling for perceived job stability, a clear positive effect emerges. Therefore in Spain the general externalities of unemployment on the employed are mainly positive and related to the comparison effect. In a recent study Oesch and Lipps (2011) report for Germany and Switzerland, that unemployment hurts alike in regions with high and low unemployment. Luechinger et al. (2010) on the contrary report for a cross section of countries (including German SOEP data), that unemployment has negative effects even on workers in employment, but more so for workers in the private than in the public sector. This is the result found in most studies on this subject -see Clark (2003), Powdthavee (2007), Clark et al. (2010), Schwarz (2012) y Hudson y Barrett (2013). The only exception relates to the study of the effect of unemployment on life satisfaction of workers in Rusia during the 1990's.

Perceived job stability is measured indirectly by means of the individual's satisfaction with job stability. An even more direct measured is offered in the 2010 survey where respondents are asked about the probability of keeping one's job in a 1 though 4 likert scale. Given the qualitative and quantitative importance of perceived job stability in our analysis, as a robustness check, we estimated 
the model on the 2010 sample including perceived probability of keeping one's job instead of satisfaction with job stability as a control. The results, shown in Table 3, are virtually identical to those offered in the sixth specification of Table 2.

Table 3. The effect of regional unemployment rates on subjective wellbeing at work

(1)

Spec. 5

\begin{tabular}{lcc} 
& Spec. 5 & Spec. 6 \\
\hline Regional Unemployment Rate & $0.013^{* * *}$ & $\begin{array}{c}0.015^{* * *} \\
(0.001)\end{array}$ \\
Probability of Keeping One's Job & $(0.002)$ & $0.122^{* * *}$ \\
& & $(0.011)$ \\
\hline Demographic and Human Capital Vars. & Yes & Yes \\
Job Characteristics & Yes & Yes \\
Personality Traits & Yes & Yes \\
Region fixed effects & Yes & Yes \\
Year fixed effects & No & No \\
\hline Observations & 6497 & 6497 \\
R-squared & 0.162 & 0.175 \\
\hline
\end{tabular}

Notes:

This table shows the regression of perceived job satisfaction on the variables of interest. The sample includes only individuals aged 16-74 who are employed in the private or public sector, and not self-employed. Regressions include a constant term together with the control variables in Table A.2. Observations are weighted using the individual weights in the ECVT. Standard errors in parentheses adjusted for clustering on the regional level. * significant at $10 \% * *$ significant at $5 \%$; ** significant at $1 \%$.

Source: ECVT and EPA 2010.

We also test the reliability of the baseline results to changes in different elements of the model. We consider different stratifications of the sample to investigate heterogeneity in the results; and we adopt different definitions of our regional unemployment variable.

The heterogeneity analysis is presented in Table 4 . In all the columns we offer the complete (equation 3 ) and the net (equation 4) effects of regional unemployment on subjective wellbeing at work. We first include self employed individuals in the sample. We then stratify by gender the sample of employees. Finally we divide the sample into public and private sector employees.

The results are generally robust to changes in the population of interest. Apparently, when considering the self-employed, male workers, and those employed in the private sector, the comparison effect is as large as to outweight the countervailing effect of increased job insecurity. Contrary to previous findings on the subject (see Luechinger et al. 2010), we find a clear positive effect of regional unemployment on private sector employees' wellbeing at work, even without controlling for perceived job stability. Controlling for subjective job insecurity only increases the magnitude of the effect. We do not find any significant effects for public sector employees. 
Table 4. Heterogeneity Analysis

\begin{tabular}{|c|c|c|c|c|c|c|c|c|c|c|}
\hline & $\begin{array}{c}(1) \\
\text { Self-employ. } \\
\text { Specif. } 5\end{array}$ & $\begin{array}{c}(2) \\
\text { Self-employ. } \\
\text { Specif. } 6 \\
\end{array}$ & $\begin{array}{c}\text { (3) } \\
\text { Males } \\
\text { Specif. 5 }\end{array}$ & $\begin{array}{c}(4) \\
\text { Males } \\
\text { Specif. } 6\end{array}$ & $\begin{array}{c}(5) \\
\text { Females } \\
\text { Specif. } 5\end{array}$ & $\begin{array}{c}(6) \\
\text { Females } \\
\text { Specif. } 6\end{array}$ & $\begin{array}{c}(7) \\
\text { Priv. sector } \\
\text { Specif. } 5\end{array}$ & $\begin{array}{c}(8) \\
\text { Priv. sector } \\
\text { Specif. } 6\end{array}$ & $\begin{array}{c}\text { (9) } \\
\text { Public sector } \\
\text { Specif. } 5 \\
\end{array}$ & $\begin{array}{c}(10) \\
\text { Public sector } \\
\text { Specif. } 6\end{array}$ \\
\hline Regional Unemployment Rate & $\begin{array}{c}0.007 * * \\
(0.003)\end{array}$ & $\begin{array}{c}0.008 * * \\
(0.003)\end{array}$ & $\begin{array}{l}0.011^{*} \\
(0.006)\end{array}$ & $\begin{array}{c}0.012 * * \\
(0.005)\end{array}$ & $\begin{array}{c}0.004 \\
(0.005)\end{array}$ & $\begin{array}{c}0.008 * * \\
(0.003)\end{array}$ & $\begin{array}{c}0.012 * * \\
(0.005)\end{array}$ & $\begin{array}{c}0.015 * * * \\
(0.003)\end{array}$ & $\begin{array}{l}-0.005 \\
(0.007)\end{array}$ & $\begin{array}{l}-0.003 \\
(0.007)\end{array}$ \\
\hline Perceived Job Stability & & $\begin{array}{c}0.158 * * * \\
(0.003) \\
\end{array}$ & & $\begin{array}{c}0.157 * * * \\
(0.004)\end{array}$ & & $\begin{array}{c}0.152 * * * \\
(0.004) \\
\end{array}$ & & $\begin{array}{c}0.167 * * * \\
(0.004)\end{array}$ & & $\begin{array}{c}0.112 * * * \\
(0.009)\end{array}$ \\
\hline Demograp. and Human Capital Vars. & Yes & Yes & Yes & Yes & Yes & Yes & Yes & Yes & Yes & Yes \\
\hline Job Characteristics & Yes & Yes & Yes & Yes & Yes & Yes & Yes & Yes & Yes & Yes \\
\hline Personality Traits & Yes & Yes & Yes & Yes & Yes & Yes & Yes & Yes & Yes & Yes \\
\hline Region fixed effects & Yes & Yes & Yes & Yes & Yes & Yes & Yes & Yes & Yes & Yes \\
\hline Year fixed effects & Yes & Yes & Yes & Yes & Yes & Yes & Yes & Yes & Yes & Yes \\
\hline Observations & 39,798 & 39,798 & 18,011 & 18,011 & 14,279 & 14,279 & 24,184 & 24,184 & 8,106 & 8,106 \\
\hline R-squared & 0.128 & 0.272 & 0.141 & 0.276 & 0.145 & 0.272 & 0.145 & 0.301 & 0.128 & 0.192 \\
\hline
\end{tabular}

Notes:

This table shows the regression of perceived job satisfaction on the variables of interest. The sample includes only individuals aged 16-74 who are employed in the private or public sector, and not self-employed. Regressions include a constant term together with the control variables in Table A.2. Observations are weighted using the individual weights in the ECVT. Standard errors in parentheses adjusted for clustering on the regional level. * significant at $10 \% * *$ significant at $5 \%$; *** significant at $1 \%$.

Source: ECVT and EPA 2006-2010. 
We further investigate the robustness of our results to different definitions of regional unemployment. In particular we consider different unemployment rates by region and gender, by region, age and gender, and by region, education, and gender. Table 5 presents the results. For most of our alternative definitions of regional unemployment and sample selections, we obtain the previous result of a clear positive effect of unemployment on the employed after controlling for perceived job security. Some definitions require the sample to be restricted also by gender to show significant results and in one of the cases, unemployment by region, age and gender, no significant effects are obtained. All in all, the results seem fairly robust, more precisely estimated for males than for females, and indicative of a clear comparison effect of general unemployment in Spain. 
Table 5. Alternative Measures of Regional Unemployment

\begin{tabular}{|c|c|c|c|c|c|c|c|c|c|c|c|c|c|c|}
\hline & $\begin{array}{c}(1) \\
\text { Tot. sample } \\
\text { Specif. } 5 \\
\end{array}$ & $\begin{array}{c}(2) \\
\text { Tot. sample } \\
\text { Specif. } 6 \\
\end{array}$ & $\begin{array}{c}\text { (3) } \\
\text { Males } \\
\text { Specif. } 5 \\
\end{array}$ & $\begin{array}{c}\text { (4) } \\
\text { Males } \\
\text { Specif. } 6 \\
\end{array}$ & $\begin{array}{c}\quad(5) \\
\text { Females } \\
\text { Specif. } 5 \\
\end{array}$ & $\begin{array}{c}\text { (6) } \\
\text { Females } \\
\text { Specif. } 6 \\
\end{array}$ & $\begin{array}{c}\text { (7) } \\
\text { Tot. sample } \\
\text { Specif. } 5 \\
\end{array}$ & $\begin{array}{c}(8) \\
\text { Tot. sample } \\
\text { Specif. } 6 \\
\end{array}$ & $\begin{array}{c}\text { (9) } \\
\text { Tot. sample } \\
\text { Specif. } 5 \\
\end{array}$ & $\begin{array}{c}(10) \\
\text { Tot. sample } \\
\text { Specif. } 6 \\
\end{array}$ & $\begin{array}{c}(11) \\
\text { Males } \\
\text { Specif. } 5 \\
\end{array}$ & $\begin{array}{c}\text { (12) } \\
\text { Males } \\
\text { Specif. } 6 \\
\end{array}$ & $\begin{array}{c}(13) \\
\text { Females } \\
\text { Specif. } 5 \\
\end{array}$ & $\begin{array}{c}\quad(14) \\
\text { Females } \\
\text { Specif. } 6 \\
\end{array}$ \\
\hline Unemp. Rate by Region and Gender & $\begin{array}{c}0.003 \\
(0.004)\end{array}$ & $\begin{array}{l}0.004 \\
(0.003)\end{array}$ & $\begin{array}{l}0.011^{*} \\
(0.005)\end{array}$ & $\begin{array}{c}0.011^{* *} \\
(0.004)\end{array}$ & $\begin{array}{c}0.005 \\
(0.005)\end{array}$ & $\begin{array}{c}0.009 * * \\
(0.004)\end{array}$ & & & & & & & & \\
\hline Unemp. Rate by Region, Age, and Gender & & & & & & & $\begin{array}{l}-0.000 \\
(0.003)\end{array}$ & $\begin{array}{l}0.001 \\
(0.002)\end{array}$ & & & & & & \\
\hline Unemp. Rate by Region, Educ., and Gender & & & & & & & & & $\begin{array}{c}0.003 \\
(0.002)\end{array}$ & $\begin{array}{c}0.006^{* * *} \\
(0.002)\end{array}$ & $\begin{array}{c}0.006^{* *} \\
(0.003)\end{array}$ & $\begin{array}{c}0.009^{* *} \\
(0.003)\end{array}$ & $\begin{array}{c}0.004 \\
(0.004)\end{array}$ & $\begin{array}{l}0.006 \\
(0.004)\end{array}$ \\
\hline Perceived Job Stability & & $\begin{array}{c}0.155^{* * * *} \\
(0.003) \\
\end{array}$ & & $\begin{array}{c}0.157^{* * * *} \\
(0.004) \\
\end{array}$ & & $\begin{array}{c}0.152 * * * \\
(0.004) \\
\end{array}$ & & $\begin{array}{c}0.155 * * * \\
(0.003) \\
\end{array}$ & & $\begin{array}{c}0.155^{* * * *} \\
(0.003) \\
\end{array}$ & & $\begin{array}{c}0.157^{* * * *} \\
(0.004) \\
\end{array}$ & & $\begin{array}{r}0.152 * * * \\
(0.004) \\
\end{array}$ \\
\hline Demographic and Human Capital Vars. & Yes & Yes & Yes & Yes & Yes & Yes & Yes & Yes & Yes & Yes & Yes & Yes & Yes & Yes \\
\hline Job Characteristics & Yes & Yes & Yes & Yes & Yes & Yes & Yes & Yes & Yes & Yes & Yes & Yes & Yes & Yes \\
\hline Personality Traits & Yes & Yes & Yes & Yes & Yes & Yes & Yes & Yes & Yes & Yes & Yes & Yes & Yes & Yes \\
\hline Region fixed effects & Yes & Yes & Yes & Yes & Yes & Yes & Yes & Yes & Yes & Yes & Yes & Yes & Yes & Yes \\
\hline Year fixed effects & Yes & Yes & Yes & Yes & Yes & Yes & Yes & Yes & Yes & Yes & Yes & Yes & Yes & Yes \\
\hline Observations & 32,290 & 32,290 & 18,011 & 18,011 & 14,279 & 14,279 & 32,290 & 32,290 & 32,290 & 32,290 & 18,011 & 18,011 & 14,279 & 14,279 \\
\hline$R$-squared & 0.134 & 0.267 & 0.141 & 0.276 & 0.145 & 0.272 & 0.134 & 0.267 & 0.134 & 0.267 & 0.141 & 0.276 & 0.145 & 0.272 \\
\hline
\end{tabular}

Notes:

This table shows the regression of perceived job satisfaction on the variables of interest. The sample includes only individuals aged 16-64 who are employed in the private or public sector, and not self-employed. Regressions include a constant term together with the control variables in Table A.2. Observations are weighted using the individual weights in the ECVT. Standard errors in parentheses adjusted for clustering on the regional level. * significant at $10 \% * *$ significant at $5 \%$; *** significant at $1 \%$.

Source: ECVT and EPA 2006-2010. 


\subsection{Ruling Out Workforce Composition Effects}

So far we have unveiled a clear comparison effect of surrounding unemployment on Spanish employees. However there remains the possibility that, because of the tremendous impact of unemployment during the current recession, the estimated positive effect is due to sample selection and not a true comparison effect. Firms may choose to lay off unproductive, less motivated workers during recessions. If this is the case, then the estimated effect of unemployment rates on workers wellbeing is a by-product of workforce selection on the part of firms. Where unemployment is higher, increased selection of more able and optimistic workers is possible and these happier workers also rate higher in their job satisfaction.

Controlling for sample selection may be difficult to achieve in the absence of panel data. Ideally we would like to restrict the sample to those who remained employed after the onset of the crisis (Askildsen et al. 2005). In the absence of such information in our dataset, we use propensity score methods to select the sample, in the spirit of Gregg et al. (2005) and Kawaguchi et al. (2012). We pair individuals from the 2006, 2007, 2008, and 2009 samples to similar individuals from the 2010 sample. This enables us to restrict the analysis sample only to those individuals who may have an analogous counterpart in the 2010 sample. Given the importance of attitudes and motivation for our research question, as a further identification strategy, we use individual information on satisfaction with private life. Methodologically however merely including satisfaction with private life as an additional control when computing the propensity score may not achieve very satisfying results. As shown by Stuart and Rubin (2008) and Borra et al. (2013), matching quality may be greatly improved by combining Mahalanobis matching on the key covariates with propensity score matching. Given the influence of gender in previous analysis of individuals' wellbeing (Clark 1997; Kaiser 2005), we consider gender and satisfaction with private life as especially relevant factors in this respect. In particular we follow the subsequent matching protocol (Rubin and Thomas 2000; Lechner 2002): For each pair of samples, for instance the 2006 and 2010 samples, we first specify and estimate a binomial probit model of the probability of belonging to the 2006 sample (our treatment group), that is, we obtain the propensity score. Second, we apply Mahalanobis metric matching on the propensity score and the key covariates considered, satisfaction with personal life and gender, within relatively refined propensity score callipers. And then we restrict the 2006 sample to observations with 'similar' individuals in the 2010 sample, that is, we impose the common support condition. Once common support samples for the four years are identified, we can perform the analysis on this restricted sample of individuals who may have belonged to the 2010 sample of workers also during 2006, 2007, 2008 and 2009.

To test the sensitivity of the results with respect to the sample selection matching algorithm, we also perform the aforementioned Mahalanobis-propensity score method including tenure as an additional key covariate. This variable is used due to its especial significance in deciding lay-offs traditionally and during the recent recession in Spain (Bentolila et al. 2010). 
Table A.3 in the Appendix assesses matching quality. It displays the mean values of the variables used in the analysis for the treatment and control groups after matching in each of the matching procedures performed - one for each survey year and matching algorithm. Overall, the figures in Table A.3 confirm that our treatment and comparison groups, though initially somewhat different, look extremely similar after matching, with very few significant differences in any of the 131 background variables used, in all of the matching procedures and sample years.

Table 6 shows the estimated effect of regional unemployment on individual wellbeing at work for the different restricted samples obtained. The first column offers the baseline estimation for the unrestricted sample for comparison purposes. The second column restricts the sample based only on the estimated propensity score. The estimates in the third column use Mahalanobis matching on life satisfaction and gender within the propensity score to restrict the sample, whereas the fourth column includes tenure in the previous method.

All coefficients are positive and significant with very little changes in the actual value of the estimate.

Table 6. The effect of regional unemployment rates on subjective wellbeing at work controlling for sample selection

Mahal. on life satisf. and Mahal. on life satisf-

Baseline Prop. Sc. gender within PS gender-tenure within PS

\begin{tabular}{lcccc} 
Regional Unempl. Rate & $0.010^{* *}$ & $0.010^{* * *}$ & $0.010^{* *}$ & $0.011^{* * *}$ \\
& $(0.003)$ & $(0.003)$ & $(0.004)$ & $(0.003)$ \\
Perceived Job Stability & $0.155^{* * *}$ & $0.155^{* * *}$ & $0.155^{* * *}$ & $0.156 * * *$ \\
& $(0.003)$ & $(0.003)$ & $(0.003)$ & $(0.004)$ \\
\hline Dem. and Human Cap Vars. & Yes & Yes & Yes & Yes \\
Job Characteristics & Yes & Yes & Yes & Yes \\
Personality Traits & Yes & Yes & Yes & Yes \\
Region fixed effects & Yes & Yes & Yes & Yes \\
Year fixed effects & Yes & Yes & Yes & 28,931 \\
\hline Observations & 32,290 & 31,745 & 30,156 & 0.262 \\
R-squared & 0.267 & 0.267 & 0.263 & \\
\hline \hline
\end{tabular}

Notes:

This table shows the regression of perceived job satisfaction on the variables of interest. In each column, the sample has been selected differently. In the first column, the sample includes only individuals aged 16-74 who are employed in the private or public sector, and not self-employed. The second and following columns include all individuals from the 2010 sample plus selected individuals from the 2006, 2007, 2008, and 2009 samples. Sample selection is based on the propensity score in columns 2, on Mahalanobis matching on satisfaction with private life and gender within propensity score calipers in column 3 and on Mahalanobis matching on satisfaction with private life, gender and tenure in column 4. Regressions include a constant term together with the control variables in Table A.2. Observations are weighted using the individual weights in the ECVT. Standard errors in parentheses adjusted for clustering on the regional level. * significant at $10 \% * *$ significant at $5 \% ; * * *$ significant at $1 \%$.

Source: ECVT and EPA 2006-2010.

We also offer results by gender in Table 7 and again results hold. If anything, women's effects tend to increase when composition of workforce is controlled for. 
Table 7. The effect of regional unemployment rates on subjective wellbeing at work by gender, controlling for sample selection

\begin{tabular}{|c|c|c|c|c|}
\hline & Baseline & Prop. Sc. & $\begin{array}{c}\text { (3) } \\
\text { Mahal. on life satisf. And } \\
\text { gender within PS }\end{array}$ & $\begin{array}{c}\text { (4) } \\
\text { Mahal. on life satisf- } \\
\text { gender-tenure within PS }\end{array}$ \\
\hline \multicolumn{5}{|l|}{ A. Males } \\
\hline Regional Unemploy Rate & $\begin{array}{c}0.011 * * \\
(0.004)\end{array}$ & $\begin{array}{c}0.012 * * * \\
(0.004)\end{array}$ & $\begin{array}{c}0.010 * * \\
(0.004)\end{array}$ & $\begin{array}{c}0.011 * * \\
(0.004)\end{array}$ \\
\hline Perceived Job Stability & $\begin{array}{c}0.157^{* * * *} \\
(0.004)\end{array}$ & $\begin{array}{c}0.158 * * * \\
(0.004)\end{array}$ & $\begin{array}{c}0.158 * * * \\
(0.005)\end{array}$ & $\begin{array}{c}0.159 * * * \\
(0.005)\end{array}$ \\
\hline Observations & 18,011 & 17,729 & 16,958 & 16,331 \\
\hline R-squared & 0.276 & 0.277 & 0.274 & 0.274 \\
\hline \multicolumn{5}{|l|}{ B. Females } \\
\hline Regional Unemploy Rate & $\begin{array}{c}0.009 * * \\
(0.004)\end{array}$ & $\begin{array}{c}0.009 * * \\
(0.004)\end{array}$ & $\begin{array}{c}0.012 * * \\
(0.005)\end{array}$ & $\begin{array}{c}0.014 * * * \\
(0.005)\end{array}$ \\
\hline Perceived Job Stability & $\begin{array}{c}0.152 * * * \\
(0.004)\end{array}$ & $\begin{array}{c}0.151 * * * \\
(0.003)\end{array}$ & $\begin{array}{c}0.150 * * * \\
(0.003)\end{array}$ & $\begin{array}{c}0.150 * * * \\
(0.004)\end{array}$ \\
\hline Observations & 14,279 & 14,016 & 13,198 & 12,600 \\
\hline R-squared & 0.272 & 0.271 & 0.268 & 0.265 \\
\hline Dem and Hum Cap Vars. & Yes & Yes & Yes & Yes \\
\hline Job Characteristics & Yes & Yes & Yes & Yes \\
\hline Personality Traits & Yes & Yes & Yes & Yes \\
\hline Region fixed effects & Yes & Yes & Yes & Yes \\
\hline Year fixed effects & Yes & Yes & Yes & Yes \\
\hline \multicolumn{5}{|c|}{$\begin{array}{l}\text { Notes: } \\
\text { This table shows the regression of perceived job satisfaction on the variables of interest. Panel A presents results } \\
\text { for men; panel B, for women. In each column, the sample has been selected differently. In the first column, the } \\
\text { sample includes only individuals aged } 16-74 \text { who are employed in the private or public sector, and not self- } \\
\text { employed. The second and following columns include all individuals from the } 2010 \text { sample plus selected } \\
\text { individuals from the 2006, 2007, 2008, and } 2009 \text { samples. Sample selection is based on the propensity score in } \\
\text { columns } 2 \text {, on Mahalanobis matching on satisfaction with private life and gender within propensity score } \\
\text { calipers in column } 3 \text { and on Mahalanobis matching on satisfaction with private life, gender and tenure in column } \\
4 \text {. Regressions include a constant term together with the control variables in Table A.2. Observations are } \\
\text { weighted using the individual weights in the ECVT. Standard errors in parentheses adjusted for clustering on the } \\
\text { regional level. * significant at } 10 \% * * \text { significant at } 5 \% \text {; ** significant at } 1 \% \text {. } \\
\text { Source: ECVT and EPA 2006-2010. }\end{array}$} \\
\hline
\end{tabular}

\section{Conclusions}

This paper investigates the association between three key variables in the labour market: wellbeing at work, job insecurity and unemployment rates. We underline the following results:

Our main finding is that, once perceived job insecurity is controlled for, general unemployment generates a positive effect on employees' wellbeing at work in Spain, larger and more precisely estimated for males and private-sector workers. This result is robust to using different regional unemployment measures, and, interestingly to controlling for workforce selection. As far as we know, no previous study has examined the effect of peers' unemployment on subjective wellbeing at work in 
the context of the Great Recession using a survey of employees. It should also be noted that such a positive impact is itself a novel finding, with the exception of Eggers et al. (2006).

Our result constitutes a microeconometric foundation of the countercyclical pattern of productivity in Spain before and during the crisis. The positive effect of unemployment on workers' wellbeing found in this paper implies that productivity varies countercyclically given that increased job satisfaction during recessions stimulates individual and organizational productivity.

From a public policy standpoint, in order to maintain productivity during periods of expansion, when others' unemployment decreases, an alternative to efficiency wages might well be efficiency job conditions, such as those related to corporate social responsibility. This sort of organizational innovations may well improve workers job effort at all wage levels.

Finally a potential extension of this paper may rest in testing whether such a strong comparison effect has also been present in other developed countries during the Great Recession or whether it has just been specific of the countries most hard hit by the recession such as Greece, Portugal and Ireland. 


\section{References}

- Akerlof, G. (1980): “A Theory of Social Custom, of Which Unemployment May Be One Consequence", Quarterly Journal of Economics, 94(4), pp. 749-775.

- Askildsen, J.E., Bratberg, E. and Nilsen, A. (2005): "Unemployment, Labor Force Composition and Sickness Absence: A Panel Data Study”, Health Economics, 14, pp. 1087-1101.

- Blanchflower, D. and Oswald, A. (2004): "Well-Being over Time in Britain and the USA", Journal of Public Economics, 87(7-8), pp. 1359-1386.

- Böckerman, P. and Ilmakunnas, P. (2010): "The Job Satisfaction-Productivity Nexus: A Study Using Matched Survey and Register Data”, Munich Personal RePEc Archive (MPRA), 17, june.

- Borjas, G.J. (1979): “Job Satisfaction, Wages and Unions”, Journal of Human Resources, 14, pp. 21-40.

- Borra, C. y Gómez, F. (2012): "Satisfacción Laboral y Salario: ¿Compensa la Renta Laboral las Condiciones no Monetarias del Trabajo?, Revista de Economía Aplicada, 60(XX), pp. 25-51.

- Borra, C., Sevilla, A. and Gerchuny, J. (2013): "Calibrating Time-Use Estimates for the British Household Panel Survey", Social Indicators Reserarch, 114, pp. 1211-1224.

- Clark, A.E. y Oswald, A.J. (1994): "Unhappiness and Unemployment”, The Economic Journal, 104, pp. 648-659.

- Clark, A.E., y Oswald, A.J. (1996): "Satisfaction and Comparison Income", Journal of Public Economics, 61, pp. 359-381.

- Clark, A., Knabe, A. and Rätzel, S. (2010): "Boon or Bane? Others' Unemployment, Well-being and Job Insecurity”, Labour Economics, 17, pp. 52-61.

- Clark, A.E. (1997): "Job Satisfaction and Gender: Why are Women so Happy at Work?", Labour Economics, 4, págs. 341-372

- Clark, A.E. (2003): "Unemployment as a Social Norm: Psychological Evidence from Panel Data", Journal of Labor Economics, 21, pp. 323-351.

- Di Tella, R., MacCulloch, R.J. and Oswald, A.J. (2001): "Preferences over Inflation and Unemployment: Evidence from Surveys of Happiness", American Economic Review, 91(1), pp. 335-341.

- Di Tella, R., MacCulloch, R.J. and Oswald, A.J. (2003): “The Macroeconomics of Happiness”, The Review of Economics and Statistics, 85(4), pp. 809-827.

- Duesenberry, J. (1949): Income, Saving and the Theory of Consumer Behavior, Harvard University Press, Cambridge, MA.

- Eggers, A., Gaddy, C. and Grahan, C. (2006): "Well-being and Unemployment in Russia in the 1990s: Can Society’s Suffering Be Individuals' Solace?, The Journal of Socio-Economics, 35, pp. 209-242.

- Easterlin, R (1974): "Does Economics Growth Improve the Human a Lot? Some Empirical Evidence", Academy Press. 
- Ferrer-i-Carbonell, A. and Frijters, P. (2004): "How Important is Methodology for the Estimates of the Determinants of Happiness? The Economic Journal, 114(497), pp. 641-659.

- Freeman, R.B. (1978): "Job Satisfaction as an Economic Variable”, American Economic Review, Papers and Proceedings, 68, pp. 135-141.

- García-Serrano, C. (2011): "Does Size Matter? The Influence of Firm Size on Working Conditions, Job Satisfaction and Quit Intentions", Scottish Journal of Political Economy, 58(2), pp. 221-247.

- Gregg, P., Washbrook, E., Propper, C. and Burgess, S. (2005): “The Effects of a Mother's Return to Worl Decision on Child Development in the UK", The Economic Journal, 115, pp. 48-80.

- Halkos, G. and Bousinakis, D. (2010): "The Effect of Stress and Satisfaction on Productivity", International Journal of Productivity and Performance Management, 59(5), pp. 415-431.

- Hammermesh, D.S. (1977): "Economic Aspects of Job Satisfaction". In: Ashenfelter, O., Oastes, W.E. (Eds.): Essays in Labour Market Analysis, pp. 53-72.

- Hudson, E. and Barrett, A. (2013): "Peer Groups, Employment Status and Mental Well-being among Older Adults in Ireland", IZA DP N 7586.

- Kahneman, D. y Krueger, A.B. (2006): "Developments in the Measurement of Subjetive Well-Being", Journal of Economic Perspectives, 20(1), pp. 3-24.

- Kaiser, L. (2005): "Gender-Job Satisfaction Differences across Europe: An Indicator for Labor Market Modernization", IZA DP N 1876.

- Kawaguchi, D., Lee, J. and Hamermesh, D.S. (2012): “A Gift of Time”, IZA DP No 6700.

- Lechner, M. (2002): "Program heterogeneity and Propensity Score Matching: An Application to the Evaluation of Active Labor Market Policies", Review of Economics and Statistics, 84, pp. 205-220.

- Locke, L.A. (1969): “What is Job Satisfaction?", Organizational Behavior and Human Performance, 4, pp. 309-336.

- Luechinger, S., Meier, S. and Stutzer, A. (2010): "Why Does Unemployment Hurt the Employed? Evidence from the Life Satisfaction Gap between the Public and the Private Sector, Journal of Human Resources, 45(4), pp. 998-1045.

- Luttmer, E. (2005): "Neighbors as Negatives: Relative Earnings and Well-Being”, The Quarterly Journal of Economics, 120(3), pp. 963-1002.

- Mangione, T.W. and Quinn, R.P. (1975): "Job Satisfaction, Counter-productive Behaviour and Drug Use at Work", Journal of Applied Psychology, 60, pp. 114-116.

- Maroto-Sánchez, A. and Cuadrado-Roura, J.R. (2013): "Recent Cyclical Movements in the Spanish Productivity. An Aggregate and Sectoral Analysis", Instituto Universitario de Análisis Económico y Social, Universidad de Alcalá, Serie DT № 6.

- Mora-Sanguinetti, J.S. and Fuentes, A.: “An Analysis of Productivity Performance in Spain Before and During the Crisis", OECD Economics Department, WP N 973. 
- Origo, F. y Pagani, L. (2009): "Flexicurity and Job Satisfaction in Europe: The Importance of Perceived and Actual Job Stability for Well-Being at Work", Labour Economics, 16(5), pp. $547-555$

- Oswald, A.J. (1997): "Happiness and Economic Performance”, The Economic Journal, 107, pp. 1815-1831.

- Phelps, E.S. and Zoega, G. (2013): "Corporatism and Job Satisfaction", Journal of Comparative Economics, 41(1), pp. 35-47.

- Powdthavee, N. (2007): "Are there Geographical Variations in the Psychological Cost of Unemployment in South Africa?, Social Indicators Research, 80, pp. 629-652.

- Pugno, M. and Depredi, S. (2009): "Job Performance and Job Satisfaction: an Integrated Survey", Università Degli Studi Di Trento, Dipartimento di Economia, Discussion Paper No 4 .

- Rubin, D.B. and Thomas, N. (2000): Combining Proponsy Score Matching with Additional Adjustments for Prognostic covariates, Journal of the American Statistical Associatin, 95, pp. 573-585.

- Schwarz, P. (2012): "Neighborhood Effects of High Unemployment Rates: Welfare Implications among Different Social Groups", The Journal of Socio Economics, 41, pp. 180188.

- Solnick, S.J. and Hemenway, D. (2005): “Are Positional Concerns Stronger in Some Domains than in Others", American Economic Review, may, pp. 147-151.

- Stuart, E.A. and Rubin, D.B. (2008): "Best Practices in Quasi-experimental designs: Matching Methods for Causal Inference. In J.W. Osborne (Ed.), Best Practices in Quantitative Methods (pp. 155-176), Thousand Oaks, CA, Sage Publications.

- Theodossiou, I. and Vasileiou, E. (2007): "Making the Risk of Job Loss a Way of Life: Does it Affect Job Satisfaction?", Research in Economics, 61, pp. 71-83.

- Van Praag, B.M.S. y Ferrer-i-Carbonell, A. (2006) "An Almost Integration-free Approach to Ordered Response Models," Tinbergen Institute Discussion Papers 06-047/3, Tinbergen Institute.

- Winkelmann, L. y Winkelmann, R. (1998): "Why are the Unemployed so Unhappy? Evidence from Panel Data”, Economica, 65, pp. 1-15.

- Wolfers, J. (2003): "Is Business Cycle Volatility Costly? Evidence from Surveys of Subjetive Well-being", International Finance, 6(1), pp. 1-26. 
Appendix

Table A.1. Regional unemployment rates

\begin{tabular}{lccccc}
\hline & $\mathbf{2 0 0 6}$ & $\mathbf{2 0 0 7}$ & $\mathbf{2 0 0 8}$ & $\mathbf{2 0 0 9}$ & $\mathbf{2 0 1 0}$ \\
\hline Andalucía & 12.68 & 12.76 & 17.83 & 25.35 & 27.97 \\
Aragón & 5.54 & 5.24 & 7.15 & 12.82 & 14.77 \\
Asturias, Principado de & 9.31 & 8.48 & 8.45 & 13.42 & 15.97 \\
Balears, Illes & 6.46 & 6.98 & 10.18 & 18.02 & 20.37 \\
Canarias & 11.68 & 10.44 & 17.36 & 26.19 & 28.70 \\
Cantabria & 6.56 & 5.90 & 7.17 & 11.99 & 13.87 \\
Castilla y León & 8.11 & 7.18 & 9.51 & 13.78 & 15.78 \\
Castilla - La Mancha & 8.81 & 7.61 & 11.59 & 18.81 & 20.99 \\
Cataluña & 6.60 & 6.55 & 9.00 & 16.25 & 17.75 \\
Comunitat Valenciana & 8.37 & 8.76 & 12.13 & 21.24 & 23.30 \\
Extremadura & 13.43 & 13.06 & 15.20 & 20.55 & 23.04 \\
Galicia & 8.48 & 7.64 & 8.73 & 12.59 & 15.40 \\
Madrid, Comunidad de & 6.37 & 6.30 & 8.69 & 14.03 & 16.08 \\
Murcia, Región de & 7.85 & 7.56 & 12.63 & 20.73 & 23.35 \\
Navarra, Comunidad Foral de & 5.30 & 4.76 & 6.72 & 10.89 & 11.85 \\
País Vasco & 6.97 & 6.12 & 6.45 & 11.04 & 10.55 \\
Rioja, La & 6.18 & 5.66 & 7.79 & 12.75 & 14.27 \\
\hline \hline
\end{tabular}


Table A.2 Control variables

\begin{tabular}{|c|c|c|c|c|c|c|}
\hline 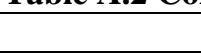 & 2006 & 2007 & 2008 & 2009 & 2010 & $2006-2010$ \\
\hline \multicolumn{7}{|c|}{ Demographic and Human Capital Characteristics } \\
\hline \multirow[t]{2}{*}{ age } & 41.97 & 41.71 & 42.08 & 41.81 & 42.84 & 42.09 \\
\hline & $(11.0)$ & $(11.2)$ & $(10.9)$ & $(10.6)$ & $(10.6)$ & $(10.9)$ \\
\hline \multirow[t]{2}{*}{ male } & 0.57 & 0.59 & 0.59 & 0.58 & 0.56 & 0.58 \\
\hline & $(0.5)$ & $(0.5)$ & $(0.5)$ & $(0.5)$ & $(0.5)$ & $(0.5)$ \\
\hline \multirow[t]{2}{*}{ inmigrant } & 0.06 & 0.11 & 0.09 & 0.11 & 0.10 & 0.09 \\
\hline & $(0.2)$ & $(0.3)$ & $(0.3)$ & $(0.3)$ & $(0.3)$ & $(0.3)$ \\
\hline \multirow[t]{2}{*}{ partner } & 0.67 & 0.66 & 0.67 & 0.68 & 0.69 & 0.67 \\
\hline & $(0.5)$ & $(0.5)$ & $(0.5)$ & $(0.5)$ & $(0.5)$ & $(0.5)$ \\
\hline \multirow[t]{2}{*}{ nhijos } & 0.50 & 0.53 & 0.48 & 0.57 & 0.54 & 0.52 \\
\hline & $(0.8)$ & $(0.8)$ & $(0.8)$ & $(0.8)$ & $(0.8)$ & $(0.8)$ \\
\hline \multirow[t]{2}{*}{ secundaria } & 0.19 & 0.20 & 0.21 & 0.23 & 0.21 & 0.21 \\
\hline & $(0.4)$ & $(0.4)$ & $(0.4)$ & $(0.4)$ & $(0.4)$ & $(0.4)$ \\
\hline \multirow[t]{2}{*}{ fp_bachiller } & 0.32 & 0.32 & 0.33 & 0.33 & 0.38 & 0.34 \\
\hline & $(0.5)$ & $(0.5)$ & $(0.5)$ & $(0.5)$ & $(0.5)$ & $(0.5)$ \\
\hline \multirow[t]{2}{*}{ universitario } & 0.25 & 0.23 & 0.26 & 0.25 & 0.26 & 0.25 \\
\hline & $(0.4)$ & $(0.4)$ & $(0.4)$ & $(0.4)$ & $(0.4)$ & $(0.4)$ \\
\hline \multirow[t]{2}{*}{ adecuado } & 0.77 & 0.79 & 0.78 & 0.78 & 0.79 & 0.78 \\
\hline & $(0.4)$ & $(0.4)$ & $(0.4)$ & $(0.4)$ & $(0.4)$ & $(0.4)$ \\
\hline \multirow[t]{2}{*}{ sobreeducado } & 0.19 & 0.15 & 0.18 & 0.18 & 0.17 & 0.17 \\
\hline & $(0.4)$ & $(0.4)$ & $(0.4)$ & $(0.4)$ & $(0.4)$ & (0.4) \\
\hline \multirow[t]{2}{*}{ nocorrespond } & 0.02 & 0.03 & 0.02 & 0.02 & 0.02 & 0.02 \\
\hline & $(0.1)$ & $(0.2)$ & $(0.1)$ & $(0.1)$ & $(0.1)$ & $(0.1)$ \\
\hline \multicolumn{7}{|c|}{ Job Characteristics } \\
\hline \multirow[t]{2}{*}{ tenure } & 10.97 & 10.50 & 10.84 & 10.69 & 11.43 & 10.89 \\
\hline & $(10.6)$ & $(10.8)$ & $(10.7)$ & $(10.5)$ & $(10.5)$ & $(10.6)$ \\
\hline \multirow[t]{2}{*}{ ln_wage } & 7.03 & 7.03 & 7.09 & 7.06 & 7.05 & 7.05 \\
\hline & $(0.6)$ & $(0.6)$ & $(0.5)$ & $(0.6)$ & $(0.6)$ & $(0.6)$ \\
\hline autonomo & 0.14 & 0.17 & 0.17 & 0.19 & 0.18 & 0.17 \\
\hline & $(0.4)$ & $(0.4)$ & $(0.4)$ & $(0.4)$ & $(0.4)$ & $(0.4)$ \\
\hline spublico & 0.21 & 0.19 & 0.20 & 0.22 & 0.20 & 0.20 \\
\hline & $(0.4)$ & $(0.4)$ & $(0.4)$ & $(0.4)$ & $(0.4)$ & $(0.4)$ \\
\hline indefinido & 0.63 & 0.61 & 0.65 & 0.63 & 0.62 & 0.63 \\
\hline & $(0.5)$ & $(0.5)$ & $(0.5)$ & $(0.5)$ & $(0.5)$ & $(0.5)$ \\
\hline tcompleto & 0.87 & 0.87 & 0.88 & 0.86 & 0.86 & 0.87 \\
\hline & $(0.3)$ & $(0.3)$ & $(0.3)$ & $(0.3)$ & $(0.3)$ & $(0.3)$ \\
\hline subord & 0.30 & 0.19 & 0.25 & 0.23 & 0.22 & 0.24 \\
\hline & $(0.5)$ & $(0.4)$ & $(0.4)$ & $(0.4)$ & $(0.4)$ & $(0.4)$ \\
\hline equipo & 0.78 & 0.74 & 0.72 & 0.78 & 0.70 & 0.74 \\
\hline & $(0.4)$ & $(0.4)$ & $(0.4)$ & $(0.4)$ & $(0.5)$ & (0.4) \\
\hline jcontinua & 0.54 & 0.51 & 0.52 & 0.53 & 0.54 & 0.53 \\
\hline & $(0.5)$ & $(0.5)$ & $(0.5)$ & $(0.5)$ & $(0.5)$ & $(0.5)$ \\
\hline horas_trabajo & 40.31 & 40.47 & 40.20 & 39.78 & 39.66 & 40.08 \\
\hline & (11.0) & $(9.9)$ & $(9.2)$ & (11.0) & (10.4) & $(10.3)$ \\
\hline unusual & 0.36 & 0.36 & 0.35 & 0.37 & 0.37 & 0.36 \\
\hline & $(0.5)$ & $(0.5)$ & $(0.5)$ & $(0.5)$ & $(0.5)$ & $(0.5)$ \\
\hline sindicato & 0.20 & 0.17 & 0.19 & 0.18 & 0.18 & 0.18 \\
\hline & $(0.4)$ & $(0.4)$ & (0.4) & $(0.4)$ & $(0.4)$ & (0.4) \\
\hline riesgo & 3.72 & 3.53 & 3.24 & 3.56 & 3.55 & 3.52 \\
\hline & $(3.2)$ & $(3.3)$ & (3.2) & $(3.1)$ & $(3.2)$ & (3.2) \\
\hline size 1 & 0.09 & 0.11 & 0.13 & 0.12 & 0.11 & 0.11 \\
\hline & $(0.3)$ & $(0.3)$ & $(0.3)$ & $(0.3)$ & $(0.3)$ & $(0.3)$ \\
\hline size2 & 0.27 & 0.25 & 0.24 & 0.24 & 0.25 & 0.25 \\
\hline & $(0.4)$ & $(0.4)$ & $(0.4)$ & $(0.4)$ & $(0.4)$ & (0.4) \\
\hline size 3 & 0.18 & 0.20 & 0.20 & 0.18 & 0.18 & 0.19 \\
\hline & $(0.4)$ & $(0.4)$ & (0.4) & $(0.4)$ & $(0.4)$ & (0.4) \\
\hline size4 & 0.13 & 0.13 & 0.13 & 0.13 & 0.14 & 0.13 \\
\hline & $(0.3)$ & $(0.3)$ & (0.3) & $(0.3)$ & $(0.3)$ & (0.3) \\
\hline size5 & 0.34 & 0.31 & 0.30 & 0.33 & 0.31 & 0.32 \\
\hline & $(0.5)$ & $(0.5)$ & $(0.5)$ & $(0.5)$ & $(0.5)$ & $(0.5)$ \\
\hline
\end{tabular}


Table A.2 Control variables (cont.)

\begin{tabular}{|c|c|c|c|c|c|c|}
\hline & 2006 & 2007 & 2008 & 2009 & 2010 & 2006-2010 \\
\hline \multicolumn{7}{|l|}{ Additional controls } \\
\hline \multirow[t]{2}{*}{ ln_income } & 7.44 & 7.42 & 7.43 & 7.47 & 7.41 & 7.43 \\
\hline & $(0.6)$ & $(0.6)$ & $(0.6)$ & $(0.6)$ & $(0.6)$ & $(0.6)$ \\
\hline \multirow[t]{2}{*}{ tamanno1 } & 0.20 & 0.22 & 0.22 & 0.23 & 0.24 & 0.22 \\
\hline & $(0.4)$ & $(0.4)$ & $(0.4)$ & $(0.4)$ & $(0.4)$ & $(0.4)$ \\
\hline \multirow[t]{2}{*}{ tamanno2 } & 0.27 & 0.27 & 0.27 & 0.26 & 0.27 & 0.27 \\
\hline & $(0.4)$ & $(0.4)$ & $(0.4)$ & $(0.4)$ & $(0.4)$ & $(0.4)$ \\
\hline \multirow[t]{2}{*}{ tamanno3 } & 0.12 & 0.12 & 0.12 & 0.12 & 0.11 & 0.12 \\
\hline & $(0.3)$ & $(0.3)$ & $(0.3)$ & $(0.3)$ & $(0.3)$ & $(0.3)$ \\
\hline \multirow[t]{2}{*}{ tamanno4 } & 0.33 & 0.32 & 0.31 & 0.31 & 0.30 & 0.31 \\
\hline & $(0.5)$ & $(0.5)$ & $(0.5)$ & $(0.5)$ & $(0.5)$ & $(0.5)$ \\
\hline \multirow[t]{2}{*}{ tamanno5 } & 0.08 & 0.07 & 0.08 & 0.08 & 0.08 & 0.08 \\
\hline & $(0.3)$ & $(0.3)$ & $(0.3)$ & $(0.3)$ & $(0.3)$ & $(0.3)$ \\
\hline \multicolumn{7}{|c|}{ Personality and attitudinal variables } \\
\hline \multirow{2}{*}{ pref_spriv } & 0.44 & 0.42 & 0.39 & 0.44 & 0.43 & 0.43 \\
\hline & $(0.5)$ & $(0.5)$ & $(0.5)$ & $(0.5)$ & $(0.5)$ & $(0.5)$ \\
\hline \multirow[t]{2}{*}{ pref_empleado } & 0.65 & 0.66 & 0.70 & 0.70 & 0.72 & 0.69 \\
\hline & $(0.5)$ & $(0.5)$ & $(0.5)$ & $(0.5)$ & $(0.4)$ & $(0.5)$ \\
\hline \multirow[t]{2}{*}{ pref_esapeq } & 0.46 & 0.41 & 0.41 & 0.43 & 0.40 & 0.42 \\
\hline & $(0.5)$ & $(0.5)$ & $(0.5)$ & $(0.5)$ & $(0.5)$ & $(0.5)$ \\
\hline \multirow[t]{2}{*}{ satis_estab } & 7.34 & 7.30 & 7.30 & 7.21 & 7.22 & 7.27 \\
\hline & $(2.5)$ & $(2.5)$ & $(2.7)$ & $(2.7)$ & $(2.6)$ & $(2.6)$ \\
\hline \multirow{2}{*}{ satis_vida } & 7.58 & 7.54 & 7.55 & 7.36 & 7.44 & 7.49 \\
\hline & $(1.9)$ & $(2.0)$ & $(1.8)$ & $(1.8)$ & $(1.8)$ & (1.9) \\
\hline \multicolumn{7}{|c|}{ Unemployment measures } \\
\hline \multirow[t]{2}{*}{ nat_unemp } & 8.51 & 8.26 & 11.34 & 18.01 & 20.06 & 13.29 \\
\hline & $(0.0)$ & $(0.0)$ & $(0.0)$ & $(0.0)$ & $(0.0)$ & $(4.9)$ \\
\hline \multirow[t]{2}{*}{ reg_unemp } & 7.92 & 7.71 & 10.48 & 16.93 & 18.83 & 12.43 \\
\hline & $(2.2)$ & (2.3) & $(3.4)$ & $(4.4)$ & $(4.8)$ & $(5.9)$ \\
\hline \multirow[t]{2}{*}{ gender_unemp } & 7.92 & 7.63 & 10.40 & 16.91 & 18.80 & 12.39 \\
\hline & (3.3) & (3.1) & $(3.8)$ & $(4.5)$ & $(5.0)$ & $(6.1)$ \\
\hline \multirow[t]{2}{*}{ age_gend_unemp } & 7.12 & 7.02 & 9.40 & 15.44 & 17.09 & 11.26 \\
\hline & $(4.2)$ & $(4.1)$ & $(5.2)$ & $(7.0)$ & $(7.3)$ & $(7.1)$ \\
\hline \multicolumn{7}{|l|}{ educ_gend_unem } \\
\hline \multirow[t]{2}{*}{$\mathrm{p}$} & 8.14 & 8.03 & 10.88 & 17.73 & 19.55 & 12.92 \\
\hline & $(4.0)$ & $(4.0)$ & $(5.3)$ & $(7.1)$ & $(7.6)$ & $(7.6)$ \\
\hline
\end{tabular}




\begin{tabular}{|c|c|c|c|c|c|c|c|c|c|c|c|c|c|c|c|c|c|c|c|c|c|c|c|c|c|}
\hline & \multirow{3}{*}{$\begin{array}{l}2010 \\
\text { Mean }\end{array}$} & \multicolumn{8}{|c|}{ Propensity Score Matching } & \multicolumn{8}{|c|}{ Mahalanobis on private life satisfaction and gender within PS calipers } & \multicolumn{8}{|c|}{ Mahalanobis on private life satisfaction, gender, and tenure within PS calipers } \\
\hline & & \multicolumn{2}{|c|}{2006} & \multicolumn{2}{|c|}{2007} & \multicolumn{2}{|c|}{2008} & \multicolumn{2}{|c|}{2009} & \multicolumn{2}{|c|}{2006} & \multicolumn{2}{|c|}{2007} & \multicolumn{2}{|c|}{2008} & \multicolumn{2}{|c|}{2009} & \multicolumn{2}{|c|}{2006} & \multicolumn{2}{|c|}{2007} & \multicolumn{2}{|c|}{2008} & \multicolumn{2}{|c|}{2009} \\
\hline & & Mean & t-test & Mean & t-test & Mean & t-test & Mean & t-test & Mean & t-test & Mean & t-test & Mean & t-test & Mean & t-test & Mean & t-test & Mean & t-test & Mean & t-test & Mean & t-test \\
\hline satis_vida & 7.40 & 7.60 & 0.04 & 7.58 & $1.73^{*}$ & 7.56 & 0.85 & 7.40 & -0.29 & 7.79 & 0.00 & 7.75 & 0.00 & 7.69 & 0.00 & 7.55 & 0.00 & 7.85 & 0.00 & 7.80 & 0.00 & 7.74 & 0.00 & 7.59 & 0.00 \\
\hline pref_spriv & 0.40 & 0.41 & $-1.78 *$ & 0.40 & -1.19 & 0.38 & -0.84 & 0.41 & 1.18 & 0.41 & -1.32 & 0.40 & 0.13 & 0.38 & 0.88 & 0.41 & -0.73 & 0.41 & $-1.92^{*}$ & 0.40 & 0.99 & 0.39 & 0.88 & 0.41 & 0.27 \\
\hline pref_emple $\sim$ & 0.80 & 0.73 & $2.63^{* * *}$ & 0.75 & -0.31 & 0.78 & 0.29 & 0.79 & -1.83 & 0.74 & 1.51 & 0.76 & -1.44 & 0.78 & -0.39 & 0.79 & 0.72 & 0.74 & 1.48 & 0.76 & -0.99 & 0.78 & -0.29 & 0.79 & -0.52 \\
\hline pref_esapeq & 0.36 & 0.42 & -0.20 & 0.38 & $-2.17^{* * *}$ & 0.38 & -0.68 & 0.38 & $2.62^{* * * *}$ & 0.42 & 1.11 & 0.38 & -0.86 & 0.38 & 0.83 & 0.38 & -0.11 & 0.41 & -1.01 & 0.38 & 0.79 & 0.38 & -0.37 & 0.38 & -0.74 \\
\hline age & 41.04 & 41.28 & 0.73 & 40.86 & $-1.88^{*}$ & 41.28 & -0.21 & 41.14 & 0.45 & 41.40 & 0.88 & 40.99 & 0.72 & 41.30 & -0.38 & 41.26 & -0.33 & 41.48 & -1.24 & 40.96 & -0.34 & 41.27 & 1.01 & 41.33 & -0.55 \\
\hline male & 0.55 & 0.55 & $-1.86^{*}$ & 0.56 & -0.51 & 0.57 & -0.09 & 0.56 & 0.97 & 0.55 & 0.00 & 0.57 & 0.00 & 0.58 & 0.00 & 0.57 & 0.00 & 0.56 & 0.00 & 0.57 & 0.00 & 0.58 & 0.00 & 0.57 & 0.00 \\
\hline inmigrant & 0.10 & 0.07 & -1.43 & 0.11 & 0.40 & 0.10 & -0.75 & 0.11 & 0.06 & 0.06 & $-1.71 *$ & 0.11 & -0.81 & 0.09 & -1.31 & 0.10 & -1.31 & 0.06 & -0.67 & 0.10 & -1.14 & 0.09 & -1.46 & 0.10 & -0.77 \\
\hline partner & 0.66 & 0.65 & $2.5 * *$ & 0.64 & 0.99 & 0.65 & 0.15 & 0.67 & 1.25 & 0.66 & 0.22 & 0.65 & 0.25 & 0.66 & -0.64 & 0.68 & 0.02 & 0.66 & -0.99 & 0.65 & 0.68 & 0.66 & 0.71 & 0.68 & 0.51 \\
\hline nhijos & 0.55 & 0.50 & 1.44 & 0.53 & $1.65^{*}$ & 0.47 & 0.78 & 0.57 & 1.63 & 0.51 & -0.02 & 0.53 & -0.02 & 0.48 & 0.69 & 0.57 & 0.78 & 0.51 & 0.18 & 0.53 & 0.95 & 0.48 & 1.04 & 0.57 & 1.43 \\
\hline secundaria & 0.20 & 0.19 & -1.52 & 0.20 & 1.47 & 0.21 & $2.09^{* * *}$ & 0.22 & $1.79^{*}$ & 0.20 & 1.56 & 0.20 & -0.55 & 0.21 & 1.13 & 0.22 & 0.43 & 0.20 & -0.63 & 0.20 & -1.41 & 0.21 & -0.25 & 0.21 & 0.79 \\
\hline fp_bachiller & 0.33 & 0.33 & 1.18 & 0.33 & 0.17 & 0.33 & -0.68 & 0.33 & 0.21 & 0.33 & 0.88 & 0.33 & 1.29 & 0.33 & 0.53 & 0.33 & -0.57 & 0.34 & 0.97 & 0.34 & 1.58 & 0.34 & 0.13 & 0.34 & 0.14 \\
\hline universita $\sim$ & 0.29 & 0.27 & 1.21 & 0.25 & -1.09 & 0.28 & -2.74 & 0.27 & $-1.91 *$ & 0.27 & -2.72 & 0.26 & -0.23 & 0.28 & -1.61 & 0.28 & 0.12 & 0.27 & -0.46 & 0.27 & 0.35 & 0.28 & -0.68 & 0.28 & 0.63 \\
\hline adecuado & 0.77 & 0.76 & -1.32 & 0.78 & -1.22 & 0.77 & 0.06 & 0.78 & 0.75 & 0.76 & -0.47 & 0.78 & 0.00 & 0.77 & -0.68 & 0.78 & 0.38 & 0.77 & -0.93 & 0.78 & -0.02 & 0.78 & 0.41 & 0.79 & 0.94 \\
\hline sobreeducado & 0.19 & 0.20 & 1.34 & 0.17 & 0.53 & 0.19 & 0.64 & 0.19 & -0.64 & 0.20 & 0.74 & 0.17 & 0.27 & 0.19 & 0.18 & 0.18 & -0.10 & 0.19 & 1.37 & 0.17 & -0.08 & 0.19 & 0.40 & 0.18 & -0.54 \\
\hline nocorrespond & 0.02 & 0.02 & -0.25 & 0.03 & $2.69 * *$ & 0.02 & -0.51 & 0.02 & -0.52 & 0.02 & -1.18 & 0.03 & -0.06 & 0.02 & 0.13 & 0.02 & -0.78 & 0.02 & -0.81 & 0.02 & 0.75 & 0.02 & -2.60 & 0.02 & -0.20 \\
\hline tenure & 9.98 & 10.39 & $1.93^{*}$ & 9.70 & -0.19 & 10.19 & -0.22 & 10.10 & 0.74 & 10.54 & 1.19 & 9.89 & 0.73 & 10.29 & 0.71 & 10.26 & 0.44 & 10.57 & -1.41 & 9.96 & -0.17 & 10.32 & 0.36 & 10.29 & -0.97 \\
\hline ln_wage & 7.06 & 7.02 & 0.46 & 7.01 & 0.73 & 7.09 & $-1.82^{*}$ & 7.07 & 0.22 & 7.03 & -1.63 & 7.03 & -0.61 & 7.10 & -0.75 & 7.08 & -0.19 & 7.04 & -1.43 & 7.04 & -0.61 & 7.10 & 1.43 & 7.09 & 1.77 \\
\hline spublico & 0.28 & 0.26 & $1.89 *$ & 0.24 & $-1.74 *$ & 0.24 & -0.68 & 0.27 & -1.06 & 0.26 & -0.04 & 0.24 & -1.23 & 0.24 & -0.39 & 0.27 & -0.27 & 0.26 & -0.13 & 0.24 & -1.13 & 0.25 & -0.15 & 0.26 & -0.04 \\
\hline indefinido & 0.79 & 0.76 & $2.85 * * *$ & 0.75 & 1.10 & 0.79 & -0.17 & 0.78 & -1.18 & 0.77 & 1.57 & 0.76 & 1.27 & 0.79 & 0.78 & 0.79 & 1.21 & 0.77 & $2.88^{* * * * *}$ & 0.77 & 3.81 & 0.79 & $3.11^{* * * *}$ & 0.79 & $1.75^{*}$ \\
\hline tcompleto & 0.85 & 0.87 & -1.08 & 0.87 & -0.61 & 0.88 & -0.55 & 0.86 & 0.59 & 0.87 & 0.03 & 0.87 & 0.73 & 0.88 & -0.03 & 0.86 & 0.29 & 0.87 & -0.52 & 0.87 & 0.42 & 0.88 & 0.82 & 0.87 & 0.85 \\
\hline subord & 0.21 & 0.29 & -0.40 & 0.17 & -0.38 & 0.23 & $-2.52 * *$ & 0.21 & -0.13 & 0.28 & $-2.3^{* *}$ & 0.18 & $-2.29^{* * *}$ & 0.24 & -1.02 & 0.21 & -0.09 & 0.28 & $-2.28 * *$ & 0.18 & -0.74 & 0.24 & -1.56 & 0.22 & 0.83 \\
\hline equipo & 0.86 & 0.84 & 0.27 & 0.82 & 0.77 & 0.82 & 0.18 & 0.85 & -0.30 & 0.84 & -0.59 & 0.83 & 0.02 & 0.82 & -1.15 & 0.86 & -0.08 & 0.84 & -0.37 & 0.83 & 0.28 & 0.82 & 0.21 & 0.86 & 0.92 \\
\hline jcontinua & 0.58 & 0.59 & -0.42 & 0.55 & 0.13 & 0.57 & 0.40 & 0.59 & 0.49 & 0.59 & 0.67 & 0.56 & -0.79 & 0.57 & -0.20 & 0.59 & 0.28 & 0.59 & 0.65 & 0.56 & -0.17 & 0.58 & -1.20 & 0.58 & -0.27 \\
\hline horas_trab $\sim 0$ & 38.60 & 39.12 & $-2.26^{* * *}$ & 39.32 & 0.49 & 39.17 & -0.12 & 38.64 & -0.17 & 39.00 & -0.74 & 39.17 & 0.31 & 39.13 & 0.62 & 38.66 & 0.31 & 38.97 & -0.55 & 39.17 & -0.43 & 39.14 & 0.40 & 38.72 & 0.61 \\
\hline unusual & 0.35 & 0.35 & 0.30 & 0.34 & 0.23 & 0.34 & 1.06 & 0.36 & 1.49 & 0.35 & -0.53 & 0.34 & -1.29 & 0.34 & -0.81 & 0.36 & 1.16 & 0.35 & -1.46 & 0.34 & -1.64 & 0.34 & -0.96 & 0.36 & 0.77 \\
\hline sindicato & 0.22 & 0.22 & 0.31 & 0.19 & 0.78 & 0.22 & 0.76 & 0.21 & -0.52 & 0.22 & 0.68 & 0.20 & 0.26 & 0.22 & 0.67 & 0.22 & -0.04 & 0.23 & 0.26 & 0.20 & 0.98 & 0.22 & 1.11 & 0.22 & 1.02 \\
\hline riesgo & 3.60 & 3.83 & -0.46 & 3.62 & -1.27 & 3.34 & 1.56 & 3.69 & 1.59 & 3.82 & 0.13 & 3.62 & 0.76 & 3.38 & 0.36 & 3.72 & 1.26 & 3.80 & 0.47 & 3.62 & -0.35 & 3.37 & 1.25 & 3.72 & 0.49 \\
\hline size1 & 0.01 & 0.01 & -1.01 & 0.01 & -0.54 & 0.03 & 2.13 & 0.01 & 0.87 & 0.01 & -0.98 & 0.01 & 0.00 & 0.02 & 1.10 & 0.01 & -1.38 & 0.01 & -1.55 & 0.01 & -1.34 & 0.02 & 0.19 & 0.01 & 0.00 \\
\hline size2 & 0.20 & 0.23 & -1.50 & 0.22 & 0.00 & 0.21 & 0.17 & 0.20 & 1.00 & 0.22 & -0.52 & 0.22 & 0.47 & 0.21 & -1.64 & 0.20 & -0.44 & 0.22 & -0.72 & 0.21 & -0.46 & 0.21 & -0.20 & 0.20 & $-2.43 * *$ \\
\hline size3 & 0.21 & 0.20 & 1.61 & 0.23 & -0.51 & 0.23 & 0.81 & 0.21 & 0.22 & 0.20 & -0.38 & 0.23 & 0.31 & 0.23 & 1.49 & 0.21 & 0.66 & 0.20 & 0.07 & 0.23 & 1.48 & 0.23 & -0.41 & 0.21 & 0.72 \\
\hline size4 & 0.17 & 0.15 & -0.15 & 0.16 & 0.39 & 0.16 & -1.05 & 0.16 & -1.26 & 0.15 & 3.24 & 0.16 & 0.71 & 0.16 & 1.19 & 0.17 & -0.25 & 0.16 & 1.69 & 0.16 & -0.26 & 0.16 & 0.97 & 0.17 & 1.16 \\
\hline size5 & 0.41 & 0.41 & 0.33 & 0.38 & 0.26 & 0.37 & -0.75 & 0.41 & -0.22 & 0.41 & -1.34 & 0.38 & -1.20 & 0.38 & -1.12 & 0.41 & 0.30 & 0.41 & -0.34 & 0.38 & -0.41 & 0.38 & -0.26 & 0.41 & 0.56 \\
\hline occupation1 & 0.00 & 0.00 & -0.17 & 0.00 & 1.14 & 0.00 & 0.56 & 0.01 & 1.49 & 0.00 & -0.82 & 0.00 & 2.04 & 0.00 & 0.85 & 0.00 & 1.94 & 0.00 & $2.13 * *$ & 0.00 & 0.17 & 0.00 & 0.70 & 0.00 & -1.05 \\
\hline occupation2 & 0.00 & 0.00 & -0.53 & 0.00 & 0.82 & 0.00 & -0.82 & 0.00 & 0.00 & 0.00 & 1.00 & 0.00 & 1.00 & 0.00 & -0.63 & 0.00 & -1.15 & 0.00 & 1.00 & 0.00 & 0.00 & 0.00 & 0.47 & 0.00 & 1.16 \\
\hline occupation3 & 0.03 & 0.02 & 0.14 & 0.03 & $1.78^{*}$ & 0.03 & -1.30 & 0.03 & -0.72 & 0.02 & -0.81 & 0.03 & 0.11 & 0.03 & 0.22 & 0.03 & -0.45 & 0.02 & -0.82 & 0.03 & 0.33 & 0.03 & -0.33 & 0.03 & -0.28 \\
\hline occupation4 & 0.00 & 0.00 & 0.28 & 0.00 & & 0.00 & $1.81^{*}$ & 0.00 & 1.34 & 0.00 & 0.90 & 0.00 & & 0.00 & -0.60 & 0.00 & -0.71 & 0.00 & 0.28 & 0.00 & & 0.00 & 0.45 & 0.00 & 0.45 \\
\hline occupation5 & 0.00 & 0.00 & 0.00 & 0.00 & $-2.24 * *$ & 0.00 & -1.53 & 0.00 & 1.73 & 0.00 & 1.41 & 0.00 & 0.00 & 0.00 & -0.63 & 0.00 & 0.45 & 0.00 & 1.41 & 0.00 & 1.00 & 0.00 & 0.38 & 0.00 & $1.73^{*}$ \\
\hline
\end{tabular}




\begin{tabular}{|c|c|c|c|c|c|c|c|c|c|c|c|c|c|c|c|c|c|c|c|c|c|c|c|c|c|}
\hline occupation6 & 0.00 & 0.00 & -0.14 & 0.00 & 0.23 & 0.00 & 1.14 & 0.00 & 0.00 & 0.00 & -0.15 & 0.00 & -0.63 & 0.00 & -0.33 & 0.00 & 1.21 & 0.00 & -0.91 & 0.00 & 0.00 & 0.00 & 0.82 & 0.00 & 0.22 \\
\hline occupation7 & 0.00 & 0.00 & -1.41 & 0.00 & 0.00 & 0.00 & $1.9^{*}$ & 0.00 & & 0.00 & -0.82 & 0.00 & -1.00 & 0.00 & -1.63 & 0.00 & & 0.00 & -1.41 & 0.00 & $-1.73^{*}$ & 0.00 & -1.28 & 0.00 & t \\
\hline occupation8 & 0.00 & 0.00 & & 0.00 & 1.00 & 0.00 & 0.58 & 0.00 & -1.34 & 0.00 & . & 0.00 & 0.00 & 0.00 & 0.00 & 0.00 & & 0.00 & & 0.00 & 1.00 & 0.00 & -0.45 & 0.00 & . \\
\hline occupation9 & 0.00 & 0.00 & 1.67 & 0.00 & 0.00 & 0.00 & 0.48 & 0.00 & & 0.00 & $1.67 *$ & 0.00 & 0.00 & 0.00 & -1.09 & 0.00 & & 0.00 & -0.28 & 0.00 & 1.00 & 0.00 & 0.17 & 0.00 & \\
\hline occupation10 & 0.01 & 0.01 & 0.12 & 0.01 & 0.61 & 0.02 & -0.07 & 0.01 & -0.31 & 0.01 & -0.12 & 0.02 & 0.15 & 0.02 & 0.58 & 0.01 & 0.57 & 0.01 & 0.24 & 0.02 & -0.45 & 0.02 & -0.21 & 0.01 & 0.51 \\
\hline occupation11 & 0.02 & 0.01 & -0.60 & 0.01 & 0.38 & 0.01 & -0.15 & 0.02 & 0.07 & 0.02 & $-2.21^{* * *}$ & 0.02 & -1.02 & 0.01 & -0.15 & 0.02 & -0.78 & 0.02 & -0.32 & 0.02 & -1.69 & 0.01 & 0.63 & 0.02 & -0.40 \\
\hline occupation12 & 0.03 & 0.04 & 0.83 & 0.03 & -0.16 & 0.04 & -1.41 & 0.03 & 0.35 & 0.04 & -1.49 & 0.03 & -0.32 & 0.04 & -0.84 & 0.03 & -0.50 & 0.05 & -0.96 & 0.03 & 0.16 & 0.04 & -0.66 & 0.04 & 0.36 \\
\hline occupation13 & 0.00 & 0.00 & -0.25 & 0.01 & 0.99 & 0.00 & -0.60 & 0.01 & 0.25 & 0.00 & -0.14 & 0.01 & 1.14 & 0.00 & -0.13 & 0.01 & 0.39 & 0.00 & -0.15 & 0.01 & 0.37 & 0.00 & -0.13 & 0.01 & 2.03 \\
\hline occupation14 & 0.01 & 0.02 & 2.47 & 0.01 & -1.53 & 0.01 & -1.19 & 0.01 & -1.09 & 0.02 & -0.88 & 0.01 & 0.11 & 0.01 & 0.61 & 0.01 & -0.33 & 0.02 & 2.20 & 0.01 & 0.36 & 0.01 & 1.16 & 0.01 & -0.96 \\
\hline occupation15 & 0.01 & 0.01 & -0.11 & 0.01 & -1.58 & 0.01 & -2.43 & 0.01 & -0.94 & 0.01 & 0.47 & 0.01 & 0.73 & 0.01 & -0.45 & 0.01 & $1.7^{*}$ & 0.01 & -0.36 & 0.01 & 1.84 & 0.01 & -0.37 & 0.01 & 0.52 \\
\hline occupation16 & 0.01 & 0.01 & -1.27 & 0.01 & 0.00 & 0.01 & 0.39 & 0.01 & -1.26 & 0.01 & -0.79 & 0.01 & 0.56 & 0.01 & -0.31 & 0.01 & 0.27 & 0.01 & -0.25 & 0.01 & 1.70 & 0.01 & -0.47 & 0.01 & 0.86 \\
\hline occupation17 & 0.02 & 0.02 & 0.20 & 0.02 & -1.91 & 0.02 & -0.76 & 0.02 & -0.33 & 0.02 & -1.05 & 0.02 & -0.21 & 0.02 & -1.67 & 0.02 & 0.61 & 0.02 & -0.76 & 0.02 & 0.59 & 0.02 & -0.63 & 0.02 & 0.55 \\
\hline occupation18 & 0.03 & 0.03 & 0.00 & 0.03 & 0.59 & 0.03 & -0.52 & 0.03 & -0.21 & 0.04 & -0.75 & 0.03 & -0.88 & 0.03 & 0.35 & 0.03 & -1.31 & 0.04 & -0.97 & 0.03 & -1.30 & 0.03 & 0.00 & 0.03 & 0.00 \\
\hline occupation19 & 0.01 & 0.02 & $2.19 * *$ & 0.01 & $-2.29 * *$ & 0.01 & 0.84 & 0.01 & -0.89 & 0.02 & -0.07 & 0.01 & -0.09 & 0.01 & -0.09 & 0.01 & -0.10 & 0.01 & -0.16 & 0.01 & 1.15 & 0.01 & 0.39 & 0.01 & -0.60 \\
\hline occupation20 & 0.04 & 0.03 & 0.76 & 0.03 & 0.55 & 0.03 & $1.71^{*}$ & 0.03 & -1.48 & 0.03 & 0.34 & 0.03 & -0.11 & 0.03 & -0.38 & 0.03 & -0.42 & 0.03 & -0.94 & 0.03 & 0.45 & 0.03 & 0.11 & 0.03 & 0.11 \\
\hline occupation21 & 0.01 & 0.01 & 0.88 & 0.01 & -0.70 & 0.01 & -0.26 & 0.01 & 1.34 & 0.01 & -0.83 & 0.01 & 0.66 & 0.01 & 1.14 & 0.01 & -0.10 & 0.01 & 1.66 & 0.01 & 0.78 & 0.01 & 0.76 & 0.01 & -0.60 \\
\hline occupation22 & 0.01 & 0.00 & $-1.95^{*}$ & 0.00 & $-2.83^{* * * *}$ & 0.00 & -0.21 & 0.00 & 0.46 & 0.00 & -0.72 & 0.00 & -0.69 & 0.00 & 1.21 & 0.00 & -1.44 & 0.00 & 0.90 & 0.00 & 0.19 & 0.00 & 1.00 & 0.00 & -1.37 \\
\hline occupation 23 & 0.03 & 0.04 & 0.90 & 0.03 & -0.22 & 0.03 & -0.44 & 0.03 & 0.71 & 0.04 & -0.14 & 0.03 & 1.14 & 0.03 & 0.17 & 0.03 & 0.52 & 0.04 & 0.15 & 0.03 & 1.77 & 0.03 & 0.98 & 0.03 & 2.09 \\
\hline occupation24 & 0.07 & 0.06 & 1.06 & 0.08 & -0.20 & 0.07 & $-1.73^{*}$ & 0.07 & -0.75 & 0.07 & 0.54 & 0.08 & -0.31 & 0.07 & -0.75 & 0.07 & -0.25 & 0.07 & 0.23 & 0.08 & 0.66 & 0.07 & 0.53 & 0.07 & -0.07 \\
\hline occupation25 & 0.01 & 0.01 & 1.54 & 0.01 & -1.61 & 0.01 & -0.24 & 0.01 & 0.09 & 0.01 & 1.39 & 0.01 & -0.22 & 0.01 & 0.25 & 0.01 & 1.07 & 0.01 & 0.00 & 0.01 & -0.43 & 0.01 & 0.26 & 0.01 & 0.00 \\
\hline occupation26 & 0.02 & 0.01 & 0.16 & 0.02 & -0.56 & 0.02 & -1.01 & 0.02 & -0.62 & 0.01 & -0.77 & 0.02 & -0.91 & 0.02 & 0.84 & 0.02 & -1.26 & 0.01 & 0.25 & 0.02 & -0.72 & 0.02 & -0.64 & 0.02 & -1.55 \\
\hline occupation 27 & 0.00 & 0.01 & 0.97 & 0.01 & 0.59 & 0.01 & -0.84 & 0.01 & 1.07 & 0.01 & 0.24 & 0.01 & 0.23 & 0.01 & 0.00 & 0.01 & -0.37 & 0.01 & -0.34 & 0.01 & 1.09 & 0.01 & -1.08 & 0.01 & 0.68 \\
\hline occupation28 & 0.00 & 0.00 & -0.78 & 0.00 & -0.83 & 0.00 & -0.38 & 0.00 & -0.58 & 0.00 & 2.00 & 0.00 & 0.33 & 0.00 & -0.71 & 0.00 & 1.00 & 0.00 & 0.45 & 0.00 & -0.71 & 0.00 & 0.00 & 0.00 & 0.00 \\
\hline occupation29 & 0.02 & 0.02 & 0.70 & 0.02 & 0.00 & 0.04 & 0.32 & 0.02 & -0.60 & 0.02 & 1.07 & 0.02 & 0.28 & 0.04 & 0.98 & 0.02 & 1.26 & 0.02 & $2.34 * *$ & 0.02 & 0.07 & 0.04 & 1.32 & 0.02 & -0.22 \\
\hline occupation30 & 0.02 & 0.02 & $3.82^{* * * *}$ & 0.01 & -1.03 & 0.01 & 1.46 & 0.01 & -1.10 & 0.01 & $3.83 * * *$ & 0.01 & 0.64 & 0.00 & 0.82 & 0.00 & -0.87 & 0.01 & $2.12 * *$ & 0.00 & -1.00 & 0.00 & 0.54 & 0.00 & 0.73 \\
\hline occupation31 & 0.01 & 0.01 & $-2.29 * *$ & 0.01 & -0.17 & 0.01 & $1.75^{*}$ & 0.01 & 0.23 & 0.01 & -0.31 & 0.01 & -1.22 & 0.01 & -0.31 & 0.01 & 1.47 & 0.02 & 1.16 & 0.01 & 1.12 & 0.01 & -1.32 & 0.01 & 0.32 \\
\hline occupation 32 & 0.01 & 0.02 & -0.51 & 0.01 & 1.43 & 0.01 & -0.60 & 0.01 & 0.98 & 0.02 & -1.37 & 0.01 & -0.27 & 0.01 & -0.71 & 0.01 & $1.83^{*}$ & 0.02 & -0.23 & 0.01 & -1.45 & 0.01 & -1.77 & 0.01 & 0.67 \\
\hline occupation33 & 0.04 & 0.05 & 0.26 & 0.04 & 0.83 & 0.04 & -0.21 & 0.05 & 0.60 & 0.05 & 0.23 & 0.04 & -1.12 & 0.04 & -0.60 & 0.05 & -1.58 & 0.05 & -1.22 & 0.04 & -0.65 & 0.04 & 0.18 & 0.05 & -0.70 \\
\hline occupation34 & 0.05 & 0.04 & -1.03 & 0.05 & -0.91 & 0.05 & 1.20 & 0.05 & -0.41 & 0.04 & 0.14 & 0.05 & 0.04 & 0.05 & 0.08 & 0.05 & -1.98 & 0.04 & -1.04 & 0.05 & 0.27 & 0.05 & 1.33 & 0.05 & -0.80 \\
\hline occupation35 & 0.02 & 0.02 & -0.27 & 0.02 & -0.72 & 0.02 & -0.14 & 0.02 & 0.56 & 0.02 & 0.14 & 0.02 & -0.55 & 0.02 & 0.86 & 0.02 & 1.70 & 0.02 & -0.88 & 0.02 & -1.09 & 0.02 & -0.82 & 0.02 & 0.96 \\
\hline occupation36 & 0.05 & 0.05 & -0.44 & 0.06 & 0.08 & 0.05 & 0.89 & 0.05 & 1.26 & 0.05 & -0.62 & 0.06 & -0.24 & 0.06 & -0.69 & 0.05 & 0.75 & 0.05 & -0.59 & 0.06 & -1.57 & 0.06 & -1.31 & 0.05 & -0.13 \\
\hline occupation37 & 0.01 & 0.01 & -1.96 & 0.01 & $-2.09 * *$ & 0.01 & -1.30 & 0.01 & -0.25 & 0.01 & -1.55 & 0.01 & $-3.2 * * *$ & 0.01 & -0.54 & 0.01 & 1.01 & 0.01 & $-2.6 * * * *$ & 0.01 & -2.34 & 0.01 & -0.34 & 0.01 & 0.56 \\
\hline occupation38 & 0.00 & 0.00 & -1.28 & 0.00 & 1.00 & 0.00 & 0.22 & 0.00 & 1.04 & 0.00 & 0.58 & 0.00 & 0.94 & 0.00 & 0.00 & 0.00 & 0.30 & 0.00 & 0.28 & 0.00 & -0.79 & 0.00 & 1.39 & 0.00 & 1.34 \\
\hline occupation39 & 0.00 & 0.00 & -0.38 & 0.00 & -0.43 & 0.00 & -0.28 & 0.00 & 0.00 & 0.00 & -0.24 & 0.00 & 1.67 & 0.00 & 1.00 & 0.00 & 1.41 & 0.00 & 0.90 & 0.00 & 0.58 & 0.00 & 1.00 & 0.00 & 1.41 \\
\hline occupation 40 & 0.00 & 0.00 & 0.00 & 0.00 & -0.83 & 0.00 & -0.63 & 0.00 & 0.58 & 0.00 & 0.00 & 0.00 & 0.33 & 0.00 & -1.51 & 0.00 & & 0.00 & 0.58 & 0.00 & -0.58 & 0.00 & -0.38 & 0.00 & -1.00 \\
\hline occupation41 & 0.01 & 0.01 & -1.06 & 0.01 & 1.20 & 0.01 & 0.34 & 0.01 & 0.95 & 0.01 & 0.98 & 0.01 & -0.95 & 0.01 & -0.44 & 0.01 & -0.31 & 0.01 & 0.90 & 0.01 & 0.30 & 0.01 & -0.23 & 0.01 & -0.42 \\
\hline occupation42 & 0.04 & 0.03 & -0.20 & 0.06 & -0.19 & 0.05 & 0.78 & 0.04 & 0.56 & 0.03 & 0.36 & 0.06 & 1.28 & 0.05 & 0.89 & 0.04 & 0.19 & 0.03 & -0.84 & 0.06 & 0.59 & 0.05 & 1.09 & 0.04 & -1.35 \\
\hline occupation43 & 0.03 & 0.03 & $-1.75^{*}$ & 0.03 & -0.61 & 0.03 & 0 & 0.03 & -1.74 & 0.03 & 0.59 & 0.03 & -0.53 & 0.03 & -0.48 & 0.03 & -0.28 & 0.03 & 0.00 & 0.03 & -1.54 & 0.03 & 0.55 & 0.03 & 0.06 \\
\hline occupation44 & 0.00 & 0.01 & 0.79 & 0.00 & -0.83 & 0.00 & 0.49 & 0.00 & 1.30 & 0.00 & 0.27 & 0.00 & -1.09 & 0.00 & -0.78 & 0.00 & -0.15 & 0.00 & 0.00 & 0.00 & 0.00 & 0.00 & 0.17 & 0.00 & 0.97 \\
\hline occupation45 & 0.00 & 0.00 & -1.14 & 0.00 & -0.85 & 0.00 & 0.56 & 0.00 & -1.48 & 0.00 & 0.45 & 0.00 & -1.15 & 0.00 & 0.00 & 0.00 & -0.87 & 0.00 & -0.21 & 0.00 & 0.00 & 0.00 & 0.19 & 0.00 & 1.61 \\
\hline occupation46 & 0.01 & 0.01 & 0.31 & 0.02 & 0.45 & 0.01 & 0.51 & 0.02 & 2.04 & 0.01 & -0.78 & 0.01 & 0.08 & 0.01 & -1.06 & 0.02 & -0.15 & 0.01 & 1.24 & 0.01 & 0.83 & 0.01 & -0.51 & 0.02 & 1.05 \\
\hline occupation47 & 0.03 & 0.02 & -0.18 & 0.03 & 0.88 & 0.02 & -1.65 & 0.03 & 0.31 & 0.02 & 0.12 & 0.03 & 1.16 & 0.02 & 0.30 & 0.03 & -2.07 & 0.02 & -0.86 & 0.03 & 0.44 & 0.02 & -0.49 & 0.03 & $-1.96 *$ \\
\hline
\end{tabular}




\begin{tabular}{|c|c|c|c|c|c|c|c|c|c|c|c|c|c|c|c|c|c|c|c|c|c|c|c|c|c|}
\hline occupation 48 & 0.00 & 0.01 & -0.63 & 0.01 & -0.59 & 0.00 & -0.24 & 0.00 & 0.30 & 0.01 & 0.92 & 0.01 & 0.25 & 0.00 & -0.61 & 0.00 & -0.16 & 0.01 & 1.09 & 0.01 & 1.09 & 0.00 & 0.40 & 0.00 & 1.46 \\
\hline occupation49 & 0.02 & 0.02 & 1.21 & 0.01 & 0.35 & 0.01 & -0.23 & 0.02 & 0.28 & 0.02 & 1.01 & 0.01 & -0.87 & 0.01 & -1.36 & 0.02 & 1.05 & 0.02 & -0.96 & 0.01 & -0.90 & 0.01 & -1.70 & 0.02 & 0.37 \\
\hline occupation 50 & 0.00 & 0.01 & -1.32 & 0.01 & -0.10 & 0.01 & -1.10 & 0.01 & 0.87 & 0.01 & -0.66 & 0.01 & 0.56 & 0.01 & 0.49 & 0.01 & 0.88 & 0.01 & -0.63 & 0.01 & -0.11 & 0.01 & 0.40 & 0.01 & 0.25 \\
\hline occupation51 & 0.00 & 0.00 & -0.49 & 0.00 & -0.20 & 0.00 & 0.50 & 0.00 & -0.54 & 0.00 & 0.79 & 0.00 & -1.42 & 0.00 & 1.39 & 0.00 & 2.07 & 0.00 & -0.71 & 0.00 & -0.43 & 0.00 & 0.83 & 0.00 & 0.00 \\
\hline occupation52 & 0.01 & 0.02 & 1.53 & 0.01 & 1.73 & 0.01 & 0.45 & 0.01 & 0.53 & 0.02 & -1.63 & 0.01 & 0.90 & 0.01 & -1.35 & 0.01 & 1.04 & 0.02 & -0.44 & 0.01 & -1.35 & 0.01 & -1.28 & 0.01 & $1.91^{*}$ \\
\hline occupation53 & 0.00 & 0.00 & 0.49 & 0.00 & 0.56 & 0.00 & -1.41 & 0.00 & 0.16 & 0.00 & -0.49 & 0.00 & -0.75 & 0.00 & 2.00 & 0.00 & -0.21 & 0.00 & -0.49 & 0.00 & 0.00 & 0.00 & -1.44 & 0.00 & -0.23 \\
\hline occupation54 & 0.02 & 0.02 & -0.41 & 0.03 & 0.32 & 0.04 & 0.00 & 0.02 & 0.33 & 0.02 & 0.36 & 0.03 & 0.82 & 0.04 & 1.22 & 0.02 & -0.97 & 0.02 & 0.07 & 0.03 & 1.19 & 0.04 & 0.95 & 0.02 & 0.20 \\
\hline occupation55 & 0.01 & 0.01 & -0.70 & 0.01 & 1.58 & 0.01 & 1.27 & 0.01 & 1.08 & 0.01 & 0.39 & 0.01 & 1.17 & 0.01 & -0.69 & 0.01 & 1.12 & 0.01 & 0.85 & 0.01 & 1.17 & 0.01 & -0.25 & 0.01 & 0.11 \\
\hline occupation56 & 0.02 & 0.01 & $-1.78^{*}$ & 0.02 & 0.07 & 0.01 & 0.09 & 0.01 & -1.37 & 0.01 & -1.25 & 0.02 & -0.08 & 0.01 & -0.59 & 0.01 & $-1.69 *$ & 0.01 & -1.15 & 0.01 & 0.68 & 0.01 & -1.02 & 0.01 & $-1.95^{*}$ \\
\hline occupation57 & 0.04 & 0.04 & -1.46 & 0.04 & -0.29 & 0.03 & 0.55 & 0.04 & 0.32 & 0.04 & 1.66 & 0.04 & -0.88 & 0.03 & 1.29 & 0.04 & $1.77^{*}$ & 0.04 & $2.26 * *$ & 0.04 & -0.65 & 0.03 & 0.46 & 0.04 & 1.03 \\
\hline occupation58 & 0.00 & 0.00 & 0.66 & 0.00 & 1.41 & 0.00 & -0.38 & 0.00 & 0.71 & 0.00 & 0.24 & 0.00 & -1.34 & 0.00 & -0.45 & 0.00 & -1.07 & 0.00 & $2.31 * *$ & 0.00 & -1.00 & 0.00 & -1.00 & 0.00 & -1.94 \\
\hline occupation59 & 0.05 & 0.07 & 1.80 & 0.06 & 3.34 & 0.05 & $3.64^{* * * *}$ & 0.05 & -0.43 & 0.06 & 3.33 & 0.06 & $3.34^{* * * *}$ & 0.05 & 3.38 & 0.05 & -0.04 & 0.06 & $2.6^{* * * *}$ & 0.05 & 1.56 & 0.05 & 1.35 & 0.05 & -1.72 \\
\hline occupation60 & 0.02 & 0.02 & 0.44 & 0.01 & -1.43 & 0.01 & -0.16 & 0.02 & -0.28 & 0.02 & 0.87 & 0.01 & 0.09 & 0.01 & -1.43 & 0.02 & 0.07 & 0.02 & 0.00 & 0.01 & -0.70 & 0.01 & -0.48 & 0.01 & 0.00 \\
\hline occupation61 & 0.01 & 0.01 & -0.61 & 0.01 & -0.62 & 0.01 & -1.03 & 0.01 & -0.73 & 0.01 & -0.37 & 0.01 & 1.07 & 0.01 & 0.11 & 0.01 & 0.11 & 0.01 & 0.53 & 0.01 & 0.82 & 0.01 & -0.22 & 0.01 & 0.62 \\
\hline occupation62 & 0.01 & 0.01 & $-2.04 * *$ & 0.01 & 1.02 & 0.01 & -0.27 & 0.01 & 0.16 & 0.01 & -1.79 & 0.01 & -0.19 & 0.01 & -1.00 & 0.01 & 1.02 & 0.01 & -1.05 & 0.01 & -0.59 & 0.01 & 1.05 & 0.01 & 0.61 \\
\hline occupation63 & 0.00 & 0.00 & 0.00 & 0.00 & & 0.00 & $1.73^{*}$ & 0.00 & & 0.00 & 0.00 & 0.00 & & 0.00 & -0.82 & 0.00 & & 0.00 & 0.00 & 0.00 & & 0.00 & -1.41 & 0.00 & \\
\hline occupation64 & 0.01 & 0.01 & -0.67 & 0.02 & 0.66 & 0.01 & -0.32 & 0.01 & 0.98 & 0.01 & -1.19 & 0.02 & -0.45 & 0.01 & 0.16 & 0.01 & -1.27 & 0.01 & 0.17 & 0.01 & -0.77 & 0.01 & -0.64 & 0.01 & -0.97 \\
\hline occupation65 & 0.01 & 0.01 & 0.30 & 0.01 & 0.16 & 0.01 & 0.28 & 0.01 & -0.10 & 0.01 & -0.29 & 0.01 & -0.61 & 0.01 & -1.40 & 0.01 & 1.13 & 0.01 & -1.62 & 0.01 & 0.37 & 0.01 & -1.28 & 0.01 & 1.31 \\
\hline occupation66 & 0.02 & 0.01 & -1.06 & 0.02 & -0.57 & 0.02 & $2.00^{* * *}$ & 0.02 & 0.19 & 0.01 & 0.80 & 0.02 & -0.58 & 0.02 & 1.11 & 0.02 & 0.67 & 0.01 & 1.31 & 0.02 & -0.15 & 0.02 & 0.28 & 0.02 & 1.28 \\
\hline industry1 & 0.06 & 0.02 & -1.47 & 0.03 & 1.41 & 0.03 & 1.25 & 0.06 & 0.15 & 0.02 & -0.73 & 0.02 & 1.11 & 0.03 & 2.47 & 0.06 & 1.25 & 0.02 & -0.43 & 0.02 & -0.50 & 0.02 & 1.01 & 0.06 & -0.16 \\
\hline industry2 & 0.05 & 0.06 & -1.03 & 0.05 & 0.29 & 0.05 & 0.53 & 0.05 & -0.41 & 0.06 & 0.91 & 0.05 & -0.21 & 0.05 & -0.65 & 0.05 & 0.91 & 0.06 & -0.42 & 0.05 & 0.48 & 0.05 & 0.30 & 0.05 & 1.06 \\
\hline industry3 & 0.09 & 0.09 & 0.38 & 0.09 & 0.35 & 0.10 & -0.44 & 0.09 & -0.15 & 0.09 & 1.22 & 0.09 & 1.18 & 0.10 & -0.39 & 0.09 & -0.29 & 0.10 & 1.42 & 0.09 & 0.63 & 0.10 & -0.83 & 0.09 & 0.00 \\
\hline industry4 & 0.03 & 0.04 & -0.45 & 0.04 & 0.29 & 0.03 & -0.70 & 0.04 & $1.84 *$ & 0.04 & -0.48 & 0.04 & 1.84 & 0.03 & 0.99 & 0.04 & 0.34 & 0.04 & -0.54 & 0.04 & 2.14 & 0.04 & 1.00 & 0.04 & 0.36 \\
\hline industry5 & 0.10 & 0.10 & -1.51 & 0.13 & -0.97 & 0.11 & 1.44 & 0.10 & -0.15 & 0.10 & -1.09 & 0.13 & -1.12 & 0.12 & -0.69 & 0.10 & -1.13 & 0.11 & -0.69 & 0.13 & 0.54 & 0.12 & 0.43 & 0.10 & -1.61 \\
\hline industry6 & 0.18 & 0.17 & 0.60 & 0.19 & 0.42 & 0.18 & 0.25 & 0.18 & -0.21 & 0.18 & -0.54 & 0.19 & -0.61 & 0.18 & -0.70 & 0.18 & 0.31 & 0.18 & -0.63 & 0.19 & -1.20 & 0.18 & -1.34 & 0.18 & 0.20 \\
\hline industry7 & 0.10 & 0.10 & -0.49 & 0.08 & -1.34 & 0.09 & -0.18 & 0.10 & -0.33 & 0.10 & 1.43 & 0.08 & 0.75 & 0.10 & 1.13 & 0.10 & -0.99 & 0.10 & 0.63 & 0.09 & 0.17 & 0.10 & 0.65 & 0.09 & 0.39 \\
\hline industry8 & 0.17 & 0.18 & $2.23^{* *}$ & 0.19 & 0.67 & 0.19 & -0.78 & 0.16 & -0.53 & 0.18 & 0.82 & 0.18 & -0.91 & 0.19 & 0.11 & 0.16 & 0.93 & 0.17 & 1.41 & 0.18 & -0.69 & 0.19 & 0.25 & 0.16 & 0.21 \\
\hline industry9 & 0.17 & 0.18 & -0.87 & 0.15 & -1.45 & 0.17 & -0.72 & 0.17 & 0.31 & 0.18 & $-2.06 * *$ & 0.16 & -0.65 & 0.17 & -0.64 & 0.17 & -0.87 & 0.18 & -1.89 & 0.16 & -0.44 & 0.17 & -0.22 & 0.18 & 0.15 \\
\hline industry10 & 0.04 & 0.06 & 1.42 & 0.05 & $1.75^{*}$ & 0.05 & 0.16 & 0.04 & 0.35 & 0.06 & 1.17 & 0.05 & 1.04 & 0.05 & 0.34 & 0.04 & 0.23 & 0.06 & 1.52 & 0.05 & 0.36 & 0.05 & 0.13 & 0.04 & -0.38 \\
\hline In_income & 7.48 & 7.45 & 1.54 & 7.42 & 1.30 & 7.45 & $-2.08 * *$ & 7.48 & 0.47 & 7.46 & -1.76 & 7.43 & -0.96 & 7.46 & -0.22 & 7.49 & -0.77 & 7.46 & -1.05 & 7.44 & $-2.03^{* * *}$ & 7.47 & 1.35 & 7.50 & 1.24 \\
\hline tamanno1 & 0.20 & 0.18 & $2.61^{* * *}$ & 0.19 & -0.71 & 0.19 & 0.57 & 0.20 & -0.76 & 0.18 & 1.53 & 0.19 & -1.15 & 0.19 & -0.52 & 0.20 & 0.21 & 0.18 & -0.43 & 0.19 & -0.91 & 0.19 & -0.46 & 0.20 & -0.09 \\
\hline tamanno2 & 0.28 & 0.27 & -0.25 & 0.27 & 1.06 & 0.27 & 1.49 & 0.27 & -1.08 & 0.27 & -0.47 & 0.27 & 2.08 & 0.27 & -0.62 & 0.27 & 0.79 & 0.27 & 0.88 & 0.27 & 0.74 & 0.27 & 0.74 & 0.27 & $2.3 * *$ \\
\hline tamanno3 & 0.11 & 0.12 & -1.17 & 0.13 & 0.11 & 0.13 & -0.77 & 0.12 & 1.54 & 0.12 & $2.18^{* * *}$ & 0.13 & 1.07 & 0.13 & 0.32 & 0.12 & 0.31 & 0.12 & 1.32 & 0.12 & 0.84 & 0.13 & 1.18 & 0.12 & -0.92 \\
\hline tamanno4 & 0.33 & 0.34 & -1.05 & 0.34 & -1.12 & 0.33 & 0.06 & 0.33 & 0.51 & 0.34 & $-2.07 *$ * & 0.34 & -0.57 & 0.33 & 1.46 & 0.33 & -0.78 & 0.34 & -0.55 & 0.34 & 0.06 & 0.32 & -0.33 & 0.32 & -0.59 \\
\hline tamanno5 & 0.08 & 0.09 & 0.06 & 0.08 & 1.14 & 0.08 & $-2.29 * *$ & 0.09 & 0.19 & 0.09 & -0.30 & 0.08 & $-1.95^{*}$ & 0.08 & -1.11 & 0.09 & -0.59 & 0.08 & -1.38 & 0.08 & -0.98 & 0.08 & -1.34 & 0.08 & -1.40 \\
\hline region1 & 0.09 & 0.08 & -1.22 & 0.10 & $-2.13 * *$ & 0.10 & 0.96 & 0.09 & 0.03 & 0.08 & -0.37 & 0.10 & -0.35 & 0.10 & 0.70 & 0.09 & 0.48 & 0.08 & -1.58 & 0.10 & -1.50 & 0.10 & 1.12 & 0.09 & -0.10 \\
\hline region2 & 0.04 & 0.04 & 0.98 & 0.04 & 0.83 & 0.03 & 0.99 & 0.04 & -1.08 & 0.04 & 0.33 & 0.04 & -1.29 & 0.03 & 0.10 & 0.04 & 0.82 & 0.04 & -0.34 & 0.04 & 0.25 & 0.03 & 0.16 & 0.04 & 0.74 \\
\hline region3 & 0.03 & 0.03 & -1.13 & 0.03 & -0.10 & 0.03 & 0.14 & 0.03 & 0.10 & 0.03 & 0.37 & 0.03 & -0.41 & 0.03 & -0.10 & 0.03 & 1.39 & 0.04 & 0.42 & 0.03 & 0.82 & 0.03 & 1.23 & 0.03 & 0.92 \\
\hline region4 & 0.03 & 0.03 & -0.10 & 0.04 & -0.66 & 0.04 & -0.67 & 0.03 & 0.22 & 0.03 & 0.60 & 0.04 & -0.35 & 0.04 & 0.48 & 0.03 & -0.16 & 0.03 & -1.67 & 0.04 & -1.05 & 0.04 & 0.10 & 0.03 & 0.22 \\
\hline region5 & 0.03 & 0.05 & 0.00 & 0.04 & 1.14 & 0.04 & 1.34 & 0.03 & 1.53 & 0.04 & -0.59 & 0.04 & 1.01 & 0.04 & 0.09 & 0.03 & 0.05 & 0.04 & 0.78 & 0.04 & 0.34 & 0.04 & 0.47 & 0.03 & 0.69 \\
\hline region6 & 0.03 & 0.02 & 0.78 & 0.03 & -0.90 & 0.03 & -0.45 & 0.03 & -1.36 & 0.03 & 0.30 & 0.03 & -0.66 & 0.03 & -0.62 & 0.03 & 0.45 & 0.02 & 0.25 & 0.03 & -1.23 & 0.03 & -0.80 & 0.03 & -0.45 \\
\hline region7 & 0.05 & 0.04 & 0.40 & 0.05 & 0.26 & 0.05 & 0.75 & 0.05 & -1.17 & 0.04 & 0.61 & 0.05 & -0.35 & 0.05 & -1.81 & 0.05 & -0.35 & 0.04 & -0.19 & 0.05 & -0.63 & 0.05 & -0.17 & 0.05 & $-2.43^{* *}$ \\
\hline
\end{tabular}




\begin{tabular}{|c|c|c|c|c|c|c|c|c|c|c|c|c|c|c|c|c|c|c|c|c|c|c|c|c|c|}
\hline region8 & 0.04 & 0.04 & 0.59 & 0.03 & $-2.27 * *$ & 0.03 & -0.94 & 0.04 & 0.71 & 0.04 & 1.41 & 0.04 & -0.93 & 0.03 & -0.19 & 0.04 & -0.90 & 0.04 & -0.52 & 0.04 & -0.31 & 0.03 & -0.82 & 0.04 & -1.15 \\
\hline region9 & 0.24 & 0.29 & 0.54 & 0.27 & 1.18 & 0.25 & 0.66 & 0.27 & $3.08^{* * * *}$ & 0.28 & 0.51 & 0.27 & 0.51 & 0.25 & 0.49 & 0.26 & 0.08 & 0.28 & -0.41 & 0.27 & 0.52 & 0.25 & -1.41 & 0.26 & -0.71 \\
\hline region10 & 0.08 & 0.08 & -1.11 & 0.06 & 0.34 & 0.07 & 0.13 & 0.07 & -1.33 & 0.08 & -1.46 & 0.06 & 0.31 & 0.07 & 0.59 & 0.07 & 1.58 & 0.08 & 1.65 & 0.06 & 0.40 & 0.07 & 0.82 & 0.07 & 1.90 \\
\hline region11 & 0.04 & 0.02 & -0.67 & 0.03 & -0.72 & 0.02 & -0.33 & 0.03 & -0.58 & 0.02 & -1.52 & 0.03 & 0.66 & 0.02 & -0.68 & 0.03 & -0.15 & 0.02 & -1.29 & 0.03 & -0.61 & 0.02 & -0.53 & 0.03 & -0.46 \\
\hline region12 & 0.05 & 0.04 & 0.09 & 0.05 & 0.17 & 0.05 & -1.00 & 0.05 & -0.17 & 0.04 & 0.28 & 0.05 & 1.01 & 0.05 & 0.65 & 0.05 & -0.09 & 0.04 & 1.59 & 0.05 & 1.63 & 0.05 & -0.53 & 0.05 & 1.60 \\
\hline region13 & 0.11 & 0.10 & 0.12 & 0.10 & $1.98^{* * *}$ & 0.11 & $-2.77 * * *$ & 0.11 & -1.07 & 0.10 & -0.12 & 0.10 & -0.49 & 0.11 & -0.87 & 0.11 & -1.79 & 0.10 & -0.32 & 0.10 & 0.54 & 0.11 & 0.75 & 0.11 & -0.69 \\
\hline region14 & 0.03 & 0.03 & -0.25 & 0.04 & 1.42 & 0.04 & 1.30 & 0.03 & 0.60 & 0.03 & $1.83^{*}$ & 0.04 & -0.78 & 0.04 & 0.71 & 0.03 & 0.31 & 0.03 & 2.39 & 0.04 & -0.30 & 0.04 & -1.33 & 0.03 & 0.69 \\
\hline region15 & 0.03 & 0.03 & $3.09 * * *$ & 0.03 & -0.84 & 0.03 & -0.39 & 0.03 & 0.17 & 0.03 & 0.78 & 0.03 & 1.15 & 0.03 & 0.26 & 0.03 & 0.11 & 0.03 & -0.45 & 0.03 & -0.33 & 0.03 & -0.16 & 0.03 & 0.66 \\
\hline region16 & 0.05 & 0.05 & -0.17 & 0.05 & $-1.84^{*}$ & 0.05 & 0.40 & 0.05 & -1.35 & 0.05 & -1.34 & 0.05 & 0.88 & 0.05 & -0.32 & 0.05 & $-1.75^{*}$ & 0.05 & 1.07 & 0.05 & 0.34 & 0.05 & 1.28 & 0.05 & -0.44 \\
\hline region17 & 0.03 & 0.02 & -1.65 & 0.02 & 1.10 & 0.02 & 0.65 & 0.02 & -0.74 & 0.02 & -1.31 & 0.02 & -0.32 & 0.02 & 0.00 & 0.02 & 1.04 & 0.02 & -0.95 & 0.02 & 0.73 & 0.02 & 0.18 & 0.02 & 0.57 \\
\hline
\end{tabular}

